\title{
Chapter 6 \\ The Present and Future Role of Insect-Resistant Genetically Modified Cotton in IPM
}

\author{
Steven E. Naranjo,*, John R. Ruberson ${ }^{2}$, Hari C. Sharma ${ }^{3}$, Lewis Wilson ${ }^{4}$, \\ and Kongming $\mathrm{Wu}^{5}$
}

\begin{abstract}
Transgenic cottons producing Cry toxins from Bacillus thuringiensis $\mathrm{Bt}$ ) provide for control of lepidopteran pests and were first commercially grown in Australia, Mexico and the USA in 1996. As of 2007, a total of six additional countries (Argentina, Brazil, China, Colombia, India, and South Africa) now grow Bt cotton on a total production area of 14 million hectares. The technology primarily provides highly selective and effective control of bollworms, which are the most damaging pests of cotton worldwide. It is estimated that between 1996 and 2005 the deployment of $B t$ cotton has reduced the volume of insecticide active ingredient used for pest control in cotton by 94.5 million kilograms and increased farm income through reduced costs and improved yields by US\$7.5 billion, with most of the benefit accrued by farmers in developing nations. Reductions in insecticide use have broadened opportunities for biological control of all cotton pests but most other pest management tactics have remained largely unchanged by the use of $B t$ cotton. However, several non-target pests have become more problematic in $B t$ cotton fields in some countries largely due to reductions in insecticide use for target pests. After 11 years of $B t$ cotton cultivation, control failures due to resistance have not been detected under field conditions. This success can be largely credited to pre-emptive resistance management based on mandated refuges and monitoring programs as well as non-mandated refuge crops and natural refuges which collectively act to dilute any resistant alleles in pest populations. New products are in the pipeline to improve the effectiveness of genetically modified cotton cultivars for resistance to lepidopteran pests, and to address other pest problems in cotton. Debate over food and environmental safety, regulatory oversight, and farming community welfare are likely to continue as the technology moves forward with new crops and new adopting countries.
\end{abstract}

\footnotetext{
${ }^{1}$ USDA-ARS, Arid-Land Agricultural Research Center, Maricopa, AZ, USA

${ }^{2}$ Department of Entomology, University of Georgia, Tifton, GA, USA

${ }^{3}$ ICRISAT, Patancheru, Andhra Pradesh, India

${ }^{4}$ CSIRO Plant Industry, Narrabri, New South Wales, Australia

${ }_{5}^{5}$ Institute of Plant Protection, Chinese Academy of Agricultural Sciences, Beijing, China

* To whom correspondence should be addressed. E-mail: Steve.Naranjo@ars.usda.gov

J. Romeis, A.M. Shelton, G.G. Kennedy (eds.), Integration of Insect-Resistant

Genetically Modified Crops within IPM Programs.

(C) Springer Science + Business Media B.V. 2008
} 


\subsection{Introduction}

Cotton was grown in more than 75 countries with a total production of 26.6 billion kilograms in 2006 (National Cotton Council, http://www.cotton.org) and supplied almost $40 \%$ of total worldwide demand for fiber. Four species of cotton (Gossypium) are cultivated worldwide, including $G$. herbaceum and $G$. arboreum, which are mainly grown in Asia, G. barbadense or long staple cotton cultivated in Egypt, India, the West Indies, and parts of the western USA and South America. Gossypium hirsutum (upland cotton), the most common species, is cultivated throughout the world. Cotton is a perennial plant, but through manipulation of irrigation, defoliants and cultivation it is grown as an annual crop. The harvestable portions of the plant are found in the cotton fruit where the primary product, lint fiber, arises from the growth of single cells on the seed surface. Cotton seed is used as animal feed or in the production of oil used in some food products.

Cotton is inhabited by a large diversity of arthropods throughout the world. Hargreaves (1948) cataloged $>1,300$ herbivorous insects on cotton worldwide. Although very few of these are of economic importance, cotton production has a long history of employing insecticides for crop protection. It is estimated that cotton accounts for about $22.5 \%$ of total insecticide use worldwide (Anonymous, 1995). Advances in various pest management technologies and practices in cotton are reducing the use and impact of insecticides (Wilson et al., 2004; Brookes and Barfoot, 2006; Naranjo and Luttrell, 2008); most prominent among these has been the use of biotechnology to enhance protection against some of the most severe pests of this crop.

The adoption and use of genetically-modified (GM) crops continues to grow rapidly worldwide. As of 2007, 23 countries were producing GM crops on a total of 114.3 million hectares (James, 2007). Cottons genetically modified to produce the selective toxin proteins of Bacillus thuringiensis (Bt; Cry1 and Cry2 proteins) have been grown commercially since 1996. All current commercial lines of $B t$ cotton are cultivars of $G$. hirsutum, however, transgenic $G$. barbadense producing $B t$ toxins was approved for limited field evaluation in Australia in late 2007. The USA, Australia and Mexico were the first countries to permit commercial cultivation of Bt cotton, followed by China and South Africa in 1997, Argentina in 1998, Colombia and India in 2002, and Brazil in 2005 (Benedict and Ring, 2004; James, 2007). Widespread cultivation of $B t$ cottons in Burkina Faso, West Africa is expected in the near future. Indonesia commercialized Bt cotton in 2001 but ceased cultivation 2 years later when regulatory permits expired. Commercial production is expected to resume there in the future. The adoption rate of $B t$ cotton in India has been unprecedented. Production there grew from about 50,000 ha in 2002 to 6.2 million hectares in 2007, a 12,300\% increase in 5 years (James, 2007). In 2007, 131 hybrids were approved for planting in India compared with 4 in 2002, the initial year of cultivation. India now grows more $B t$ cotton than any other country in the world. Pakistan, one of the five largest producers of cotton in the world, has developed several indigenous $B t$ cotton varieties and wide-scale testing is on-going. 
Worldwide, about 10.8 and 3.2 million hectares of $B t$ cotton and cotton containing both insect resistance and tolerance to herbicides were grown commercially in 2007, respectively (James, 2007). One commercial Bt cotton genotype in China also expresses the cowpea trypsin inhibitor in addition to a fusion Cry1A Bt protein, but it is used only on a small scale. Cotton production statistics and $B t$ cotton adoption in these nine countries is summarized in Table 6.1.

Many issues underpin the complex nature of developing robust and sustainable pest management strategies for the cotton system. This chapter will expand upon the opportunities and challenges of integrating $B t$ cotton into current and developing IPM systems throughout cotton production regions of the world.

Table 6.1 Summary production statistics and events for Bt cotton adopting countries, 2006

\begin{tabular}{|c|c|c|c|c|c|c|}
\hline Country & $\begin{array}{l}\text { Yield } \\
\text { (million } \\
\mathrm{kg} \text { ) }\end{array}$ & $\begin{array}{l}\text { Total ha } \\
(1,000 \mathrm{~s})\end{array}$ & $\% B t$ & $\begin{array}{l}\text { First } B t \\
\text { production }\end{array}$ & Events & Insect toxins \\
\hline \multirow[t]{3}{*}{ China } & 7,729 & 6,000 & 65 & 1997 & MON531 & Cry1Ac \\
\hline & & & & & GK12 & Cry $1 A^{a}$ \\
\hline & & & & & SGK321 & Cry $1 A^{a}+$ CpTI \\
\hline \multirow[t]{4}{*}{ India } & 4,746 & 9,166 & 41 & 2002 & MON531 & Cry1Ac, \\
\hline & & & & & MON15985 & Cry 1 Ac + Cry $2 A b 2$ \\
\hline & & & & & GFM & Cry1Ab + Cry1Ac \\
\hline & & & & & Event-1 & Cry1Ac \\
\hline \multirow[t]{6}{*}{ USA } & 4,700 & 5,152 & 66 & 1996 & MON531 & Cry1Ac \\
\hline & & & & & MON15985 & Cry $1 A c+$ Cry2Ab2 \\
\hline & & & & & MON531 × $1445^{\mathrm{b}}$ & Cry1Ac \\
\hline & & & & & MON15985 × 1445 b & Cry $1 A c+$ Cry $2 A b 2$ \\
\hline & & & & & MON15985 $\times 88913^{b}$ & Cry $1 A c+$ Cry $2 A b 2$ \\
\hline & & & & & DAS21023 × 24236 & Cry $1 \mathrm{Ac}+$ Cry $1 \mathrm{~F}$ \\
\hline Brazil & 1,524 & 1,094 & 11 & 2005 & MON531 & Cry1Ac \\
\hline \multirow[t]{4}{*}{ Australia } & 294 & $145^{\mathrm{c}}$ & 83 & 1996 & MON531 & Cry1Ac \\
\hline & & & & & MON15985 & Cry $1 \mathrm{Ac}+$ Cry $2 \mathrm{Ab} 2$ \\
\hline & & & & & MON15985 × $1445^{\mathrm{b}}$ & Cry $1 \mathrm{Ac}+$ Cry $2 \mathrm{Ab} 2$ \\
\hline & & & & & MON15985 $\times 88913^{b}$ & Cry $1 \mathrm{Ac}+$ Cry $2 \mathrm{Ab} 2$ \\
\hline Argentina & 174 & 400 & 67 & 1998 & MON531 & Cry1Ac \\
\hline \multirow[t]{2}{*}{ Mexico } & 141 & $115^{\mathrm{d}}$ & 19 & 1996 & MON531, & Cry1Ac \\
\hline & & & & & MON531 $\times 1445^{b}$ & Cry1Ac \\
\hline Colombia & 41 & 53 & 42 & 2002 & MON531 & Cry1Ac \\
\hline \multicolumn{7}{|l|}{ South } \\
\hline Africa & 12 & 16 & 82 & 1997 & MON531, & Cry1Ac \\
\hline & & & & & MON15985 & Cry1Ac + Cry2Ab2 \\
\hline
\end{tabular}

Summarized from National Cotton Council (www.cotton.org), James (2006), and the AgBios Database (www.agbios.com). Countries are ranked in order of their total cotton yield. SGK321 also produced a cowpea trypsin inhibitor $(\mathrm{CpTI})$

${ }^{a}$ This Cry1A toxins represents a fusion of Cry1 Ac and Cry1 Ab expressed as a single event ${ }^{\mathrm{b}}$ MON1445 and MON88913 represent events conferring tolerance to the herbicide glyphosate ${ }^{c}$ Production in Australia was depressed in 2006 due to continued drought; the adoption rate is consistent with recent years

${ }^{\mathrm{d}} \mathrm{GM}$ cotton seed supply was disrupted in 2006 due to regulatory issues; adoption in 2005 was $>90 \%$ 


\subsection{IPM of Target and Non-Target Pests}

\subsubsection{General Considerations}

Modern pest control is guided by the principles of integrated pest management (IPM) that have been articulated by numerous authors for more than 50 years. Kogan (1998) defined IPM as "a decision support system for the selection and use of pest control tactics, singly or harmoniously coordinated into a management strategy, based on cost/benefit analyses that take into account the interests of and impacts on producers, society, and the environment." The use of GM crops, which have biological activity against select insect pests, qualifies as one of the many tactics that can be integrated into pest management strategies for cotton (Fig. 6.1). Caterpillars, particularly the various species referred to as bollworms, are among the most damaging insect pests of cotton in most parts of the world. Within this context, $B t$ cottons are virulent and selective forms of host plant resistance that represent both opportunities and challenges. Aside from the obvious opportunities for improved caterpillar control, the interactions and synergies from a single tactic such as host plant resistance may provide benefits beyond its narrow range of direct control on a specific group of pest species. Thus, although $B t$ cotton directly controls only lepidopteran pests, the associated reduction in insecticide use for these pests may facilitate or enhance the effectiveness of other tactics such as biological control which in turn may directly contribute to control of other pests in the system (e.g., Naranjo, 2001; Wu and Guo, 2003). Further, the large scale adoption of Bt

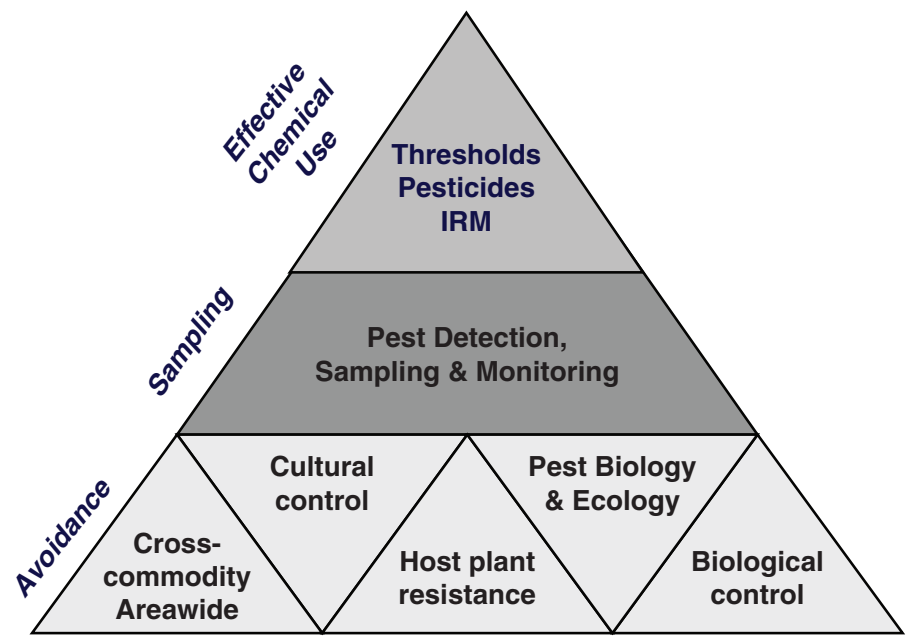

Fig. 6.1 Conceptual diagram of IPM emphasizing the importance of the underlying foundation of pest avoidance through components such as insect-resistant GM varieties and biological control (Modified from Naranjo, 2001; with permission from Elsevier) 
cotton in many countries underpins an area-wide suppression of target pests that greatly reduces overall regional populations that can have positive "halo" effects in conventional cotton (e.g., Carrière et al., 2003; Wilson et al., 2004; Storer et al., chapter 10). At the same time, there are significant challenges with using Bt cotton, the foremost of which is the potential for the development of resistance to $B t$ toxins in populations of the target pests leading to failure of this control tactic. Other challenges are manifested through the wide diversity of pests affecting cotton worldwide. For example, $B t$ cotton may indirectly cause existing primary pests or secondary pest problems to increase (Wu et al., 2002b; Lei et al., 2003; Williams, 2006). Still more challenges center on the continuing debate on ecological effects and environmental safety of $B t$ cotton and other GM crops (Marvier et al., 2007).

\subsubsection{Target Pests}

As previously noted, the $B t$ Cry toxins produced in all current commercialized GM cottons have specific activity against various lepidopteran pests (Table 6.2). In countries adopting $B t$ cottons there are roughly 30 species or groups of caterpillar pests of concern. The primary targets of the first generation of single gene transgenic cottons producing Cry1 or Cry2 were the species of the bollworm/budworm complex (Heliothis and Helicoverpa spp.), the pink bollworm (Pectinophora gossypiella), and various spiny and spotted bollworms (Earias spp.). These cottons also have good activity against various other pests such as leafworms, leaf perforators, semiloopers and other bollworms. However, single gene cottons have limited activity against pests such as Spodoptera spp., Trichoplusia ni, Pseudoplusia includens and cutworms (Benedict and Ring, 2004). The recently introduced pyramided or dual gene transgenic cottons (e.g., Bollgard II, WideStrike) produce two different Cry toxins and have a broader spectra of activity within the Lepidoptera, including efficacy against many of the pests not previously controlled effectively by single gene constructs, and improved efficacy of the initial primary targets, most notably H. zea and H. armigera (Fitt and Wilson, 2000; Adamczyk et al., 2001; Chitkowski et al., 2003; Adamczyk and Gore, 2004). Since the 2004/05 season, dual gene $B t$ cottons are now grown exclusively in place of single gene constructs in Australia and use of dual gene $B t$ cottons in the USA grew from about $14 \%$ of all $B t$ cottons in 2006 to nearly 34\% in 2007 (USDA, 2006, 2007). In Australia, Mexico and the USA, single or double $B t$ gene events are now frequently stacked with genes conferring tolerance to certain herbicides (see Table 6.1).

\subsubsection{Non-Target Pests and Changing Pest Problems}

A relatively large number of pest species that are not susceptible to the $B t$ toxins expressed in transgenic cottons affect cotton production worldwide (Table 6.3). In 


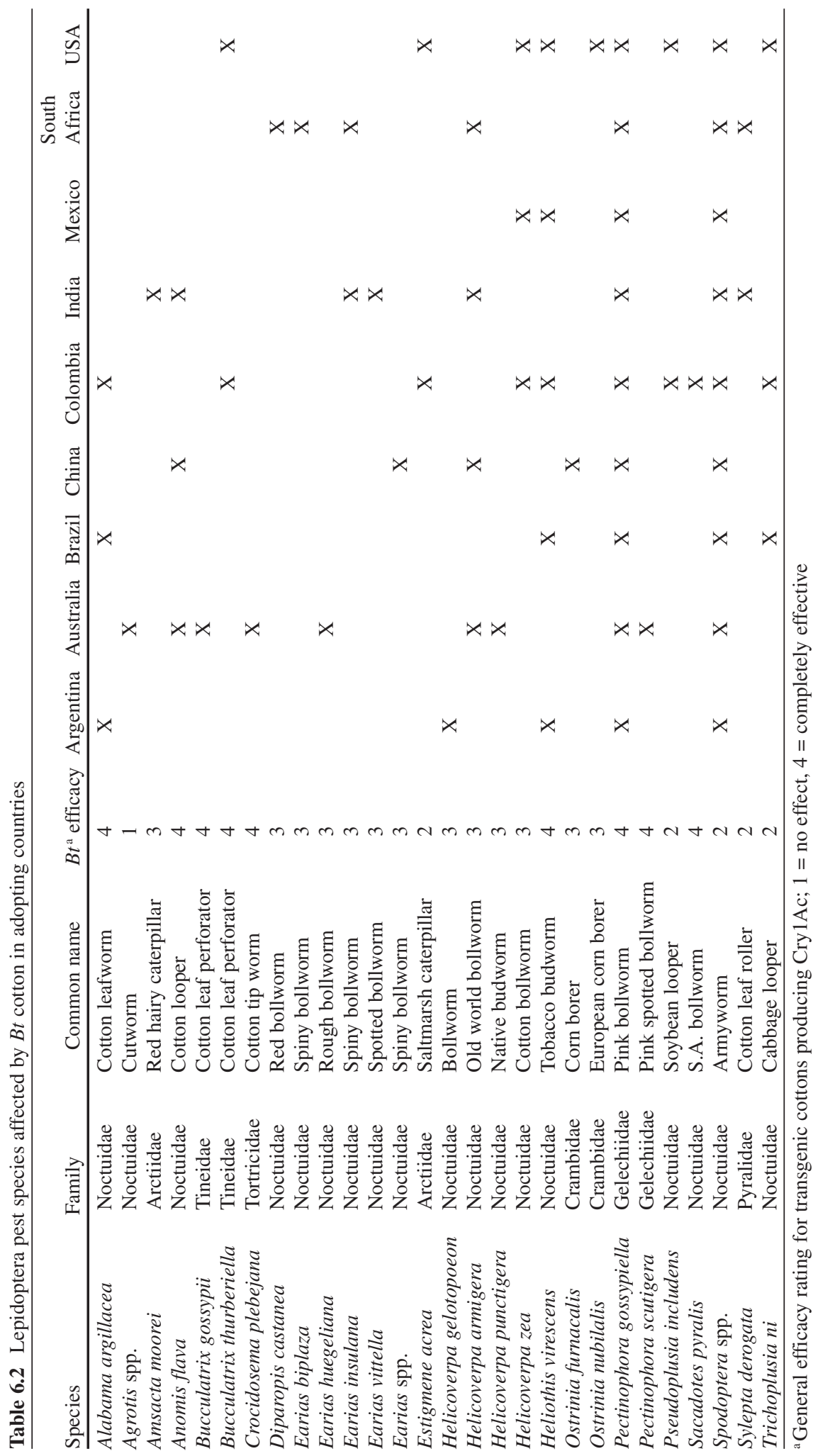




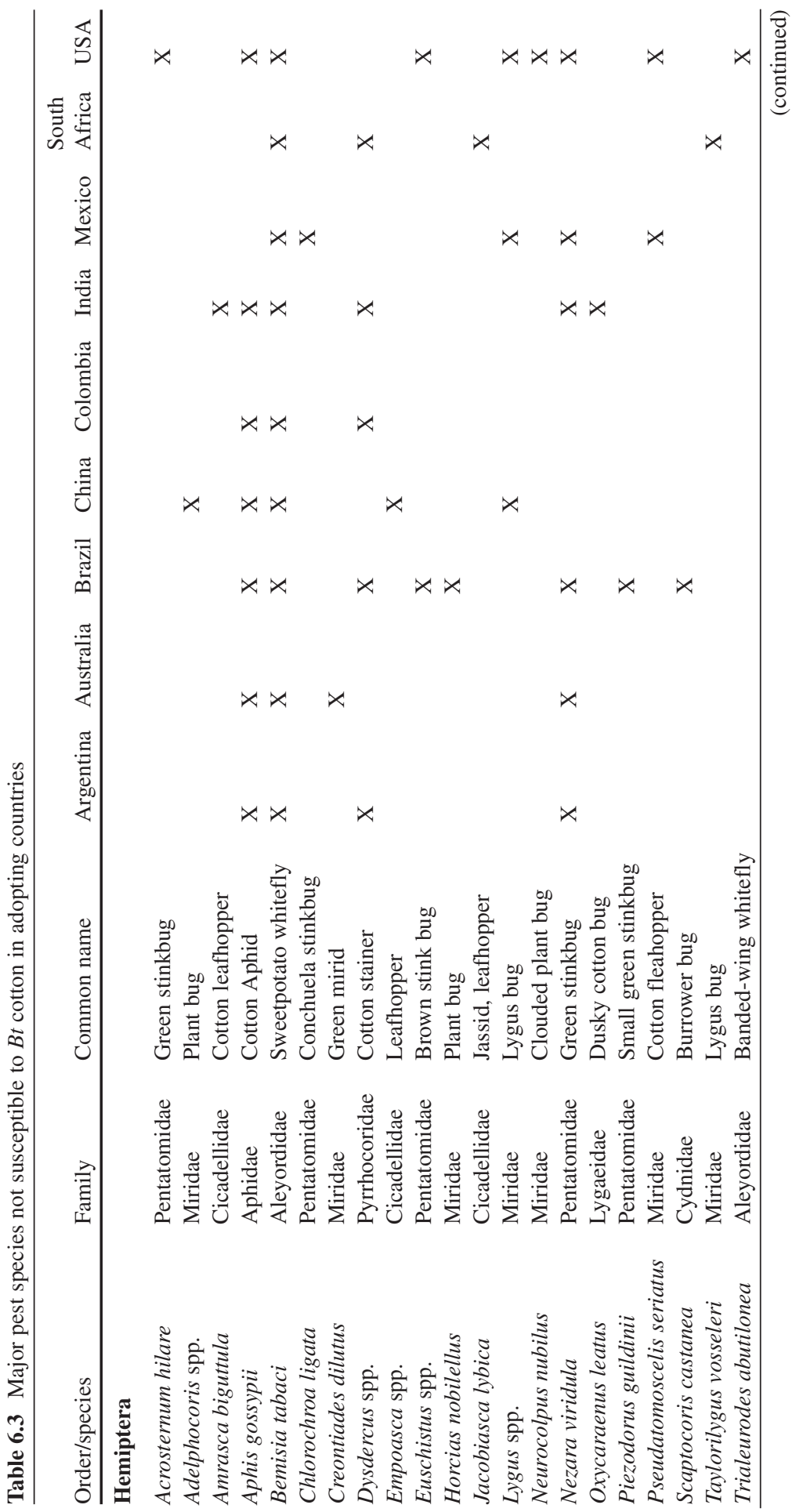




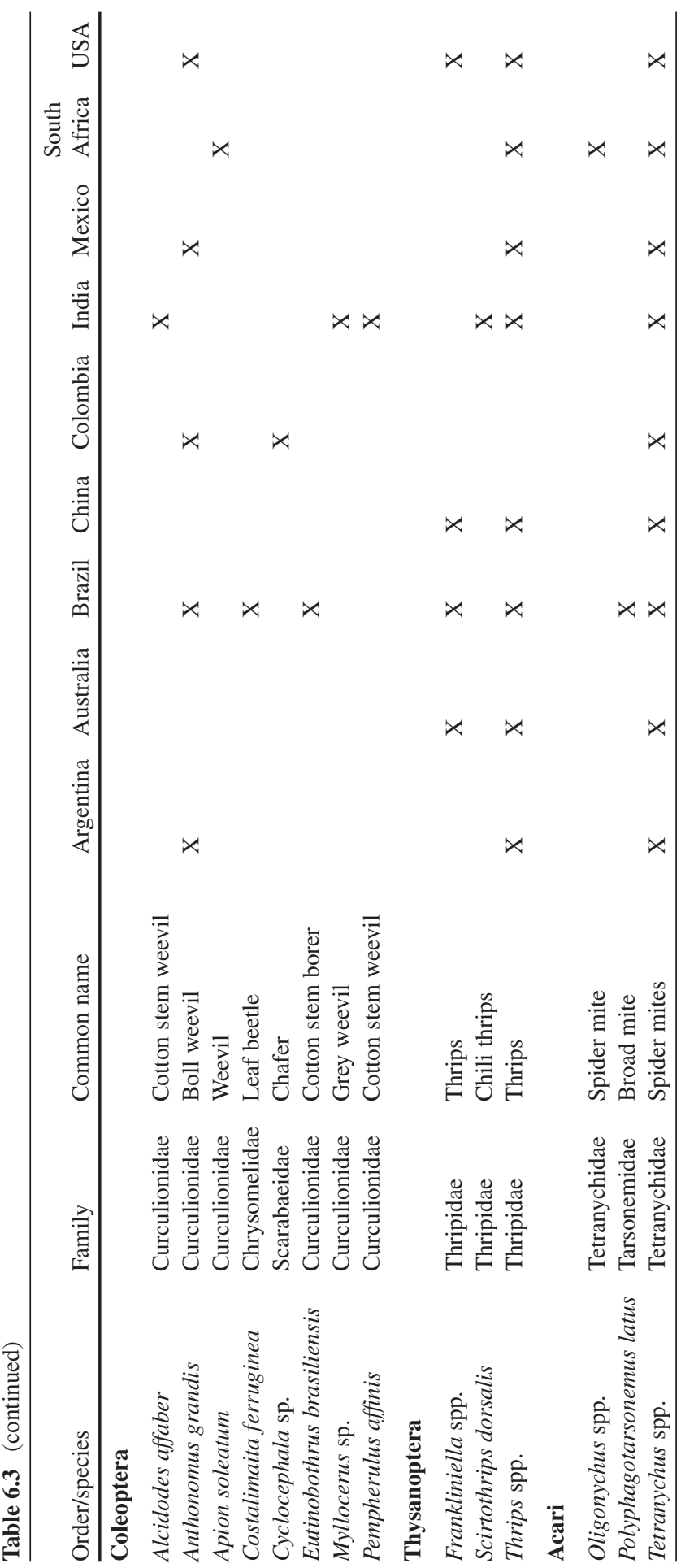


general, most of these species exhibit the same pest status and continue to be managed identically in $B t$ and conventional cotton systems. However, the use of $B t$ cottons has led to indirect effects on some of these non-target pest species in some productions systems and this is generally thought to be primarily due to reduced insecticide use for caterpillars which previously provided collateral control. In Australia, the reduced use of insecticides for bollworms has allowed some pests to become more prominent. These include the green mirid (Creontiades dilutus) (Lei et al., 2003), green vegetable bug (Nezara viridula), leaf hoppers (Austroasca viridigrisea and Amrasca terraereginae), and thrips (Thrips tabaci, Frankliniella schultzei and F. occidentalis) (Wilson et al., 2006). Of these the green mirid is most significant and is now sprayed as many as three times per season (Doyle et al., 2006) with broad spectrum insecticides (Khan et al., 2006). These products are disruptive to a wide range of natural enemies and their use has in turn been linked with increased risk of spider mites (Tetranychus urticae), aphids (Aphis gossypii), and whitefly (Bemisia tabaci B biotype) outbreaks (Wilson et al., 1998; Farrell et al., 2006). This pattern of increased importance of sucking pests, particularly mirid plant bugs, in association with reduced insecticide use for caterpillar pests has played out in other countries. In northern China a complex of mirid plant bugs (Adelphocoris suturalis, A. lineolatus, A. fasciaticollis, Lygus lucorum, and L. pratensis) have become key insect pests in Bt cotton fields in recent years (Wu et al., 2002b). Leafhoppers (Empoasca biguttula), cotton aphids (Aphis gossypii) and spider mites (Tetranychus cinnabarinus) have been observed to occur at higher levels in $B t$ cotton in Henan Province (Deng et al., 2003; Men et al., 2005). Likewise, mirid plant bugs (Lygus spp., Neurocolpus nubilus) and stinkbugs (e.g., Nezara viridula) have increased in pest status since the adoption of Bt cottons in the USA, particularly in the mid-southern and southeastern production areas (Williams, 2006). Plant bugs also have become more problematic in South Africa (Gouse et al., 2004). Finally, the reduction in insecticide sprays, especially during both the flowering and boll formation phases, in India has been associated with resurgence of some minor pests such as tobacco caterpillar (Spodoptera litura), mealy bugs (Pseudococcus corymbatus, Pulvinaria maxima, and Saissetia nigra), thrips (Thrips tabaci) and leafhoppers (Amrasca biguttula biguttula) (Sharma et al., 2005). Many of these emergent pests are easily controlled with insecticides and other pest management tactics. In contrast, lepidopteran pests, particularly those feeding within fruiting structures, are among the most difficult to control and $B t$ cotton is a key tactic for their suppression.

The reduction of insecticide use in $B t$ cotton is the likely factor explaining resurgence in some non-target pests, but other factors may be involved as well. Reduced competition from target species may enable non-target pest populations to thrive. Negative effects of $B t$ cotton on natural enemy populations might also lead to enhanced non-target pest problems. However, the bulk of evidence to date suggest that $B t$ crops are highly selective and that negative effects, if any, are relatively minor in magnitude (Naranjo et al., 2005; Romeis et al., 2006; Marvier et al., 2007). Thus, it is more likely that problematic non-target pests are not under good biological control even in conventional systems. 


\subsubsection{Decision-Making}

Sampling and use of economic thresholds for determining the need for control actions are fundamental components of even the most basic IPM programs. The decision to employ $B t$ cotton for caterpillar control is made at planting time before pest populations can be assessed. Thus, the use of $B t$ cotton is most often associated with production areas where caterpillar pests are always a threat. For example, cotton producers in the San Joaquin Valley of California, USA do not use Bt cotton because there are no significant lepidopteran pests in this region. Its use also may be associated with risk aversion (insurance), or the simple decision to eliminate any potential need for insecticidal control of caterpillars. However, the grower must weigh the potential benefits against the additional cost of the technology. Excepting greater vigilance and awareness of plant bugs and other pests that have shown a pattern of increasing in $B t$ cotton, identical decision-making protocols generally apply to non-target pests in both $B t$ and conventional production fields. However, mainly because $B t$ cottons producing only Cry1Ac toxins are not completely effective against Helicoverpa spp., growers must continue to monitor populations of these pests. In most $B t$ adopting countries there have been slight modifications to sampling protocols and thresholds for the major target pests in $B t$ cotton fields. For example, monitoring eggs to estimate the abundance of Helicoverpa spp., which is commonly employed in conventional cotton, is not useful because only the larval stages are susceptible to $B t$ toxins. In Australia, the threshold for conventional cotton is 2 larvae or 1 large larvae $(>8 \mathrm{~mm}) /$ meter-row, while in $B t$-cotton the threshold is 2 larvae $(>3 \mathrm{~mm}) /$ meter-row on two consecutive checks of a $B t$ field or 1 large larvae/m (Farrell et al., 2006). The 'consecutive sample' threshold for larvae $>3 \mathrm{~mm}$ accounts for the fact that these smaller larvae will usually quickly succumb to the toxin. If larvae were still present on the second sampling date, usually 2-3 days later, this may indicate poor efficacy of the $B t$-cotton, probably due to poor expression (but also potentially due to resistance) and additional control measures may be required. Similarly, in the USA sampling concentrates on older (2-3 days old) larvae and use of a lower threshold level than conventional cotton. Focus on slightly older larvae helps to identify populations not being effectively controlled by the $B t$ toxins but still of a size amenable to control with available insecticides (Farm Press, 2006). The lower thresholds in both cases reflect the fact that larger larvae, which are the focus of sampling, are capable of greater damage if left untreated. A similar strategy is employed for $H$. armigera in China ( $\mathrm{Wu}$ and Guo, 2005). Another key target of $B t$ cotton, the pink bollworm, is very effectively controlled by the technology. Nonetheless, scouting for this pest is still recommended, for example, in the southwestern USA. In this instance, the standard methods of sampling adults with pheromone traps and assessment of bolls for larval damage are modified to sampling for later instar larvae (3rd and 4th) within slightly older bolls (Ellsworth, 1997). It is also recommended that growers use monitoring of non-Bt refuge fields (see below) as indicators of if and when sampling should be conducted in nearby $B t$ fields. 


\subsubsection{Biological Control}

Worldwide, cotton supports large and diverse arthropod natural enemy communities (Whitcomb and Bell, 1964; Bishop and Blood, 1977; Zhao, 1984; Romeis and Shanower, 1996; Dippenaar-Schoeman et al., 1999) and there is ample evidence to suggest that these natural enemies can have a significant impact on cotton pest population dynamics (e.g., Eveleens et al., 1973; Bottrell and Adkisson, 1977; Abdelrahman and Munir, 1989; Trichilo and Wilson, 1993; Devine et al., 1998; Wilson et al., 1998; Sharma et al., 2007). Reduced insecticide use due to adoption of $B t$-transgenic cotton, the growing availability and use of selective insecticides, and improvements in other pest management tactics, have created significant opportunities for biological control in the cotton system.

Classical or introductory biological control has been attempted for various exotic pests of cotton but impact on pest populations has been generally minimal (King et al., 1996). With the exception of China, which has active programs in mass production and release of egg and larval parasitoids for control of bollworms (Wu and Guo, 2005), and India where limited releases of Trichogramma spp. (Hymenoptera: Trichogrammatidae) and Chrysoperla carnea (Neuroptera: Chrysopidae) are practiced (Sithanantham et al., 2005), augmentation has also seen limited success for control of cotton pests in other parts of the world. Conservation biological control, which relies on the preservation, manipulation and/or enhancement of existing natural enemies in the system, is the most widely practiced and successful form of biological pest control in cotton worldwide. For the most part, conservation biological control is achieved with relatively little or no overt action by growers other than consideration of the types of insecticides used, when necessary, to achieve pest control. Use of $B t$ cotton along with other changes in pest management practices have led to generally higher populations of natural enemies in cotton systems in many parts of the world (e.g., Sharma and Ortiz, 2000; Wilson et al., 2004; Naranjo et al., 2004; Wu and Guo, 2005). A reduction in natural enemies that may specialize on pests targeted by $B t$ cotton or other selective control methods is expected (Sisterson and Tabashnik, 2005) and this phenomenon has been exemplified for a specialist parasitoid in the corn system (Pilcher et al., 2005).

The tangible benefits of improved conservation of natural enemy populations in $B t$ cotton have been demonstrated in several systems. In northern China, Wu and Guo (2003) have shown that cotton aphids that are resistant to various insecticides used to control bollworms in cotton are effectively suppressed by natural enemies in $B t$ cotton fields where such sprays are unnecessary. In contrast, insecticides used to control bollworms in non- $B t$ cotton fields disrupt natural enemies leading to outbreaks of aphids. In the western USA and Australia, whiteflies (Bemisia tabaci) can be suppressed long-term in cotton fields with a single initial application of selective insecticides in comparison with fields sprayed with broad-spectrum insecticides where repeated applications are necessary. Bt cotton underpins this successful whitefly management strategy by reducing or eliminating sprays needed to control caterpillar pests (Naranjo, 2001; Ellsworth and Martinez-Carrillo, 2001). In the 
mid-southern USA, a cotton aphid threshold has been developed that incorporates the naturally occurring fungus Neozygites fresenii (Steinkraus et al., 1996) and aphid predators and parasitoids, allowing growers to actively and effectively integrate natural enemies into their treatment decisions (Chappell et al., 2005). This threshold is feasible because of the insecticide reductions resulting from boll weevil eradication and adoption of $B t$ cotton.

\subsubsection{Other Tactics}

A wide variety of additional IPM tactics such as cultural control through manipulation of production practices like intercropping, irrigation, fertilization, and cultivar and planting date selection; behavioral control utilizing semiochemicals; and chemical control continue to play important roles in management of pests in both $B t$ and non-Bt cotton (see Naranjo and Luttrell, 2008, for recent review). Over many decades, traditional host plant resistance has produced cotton traits with resistance to insects including crop earliness, morphological traits such as nectariless, glabrous or pilose leaf surface, okra-shaped leaf, frego bract, red plant color, and higher concentrations of plant secondary compounds such as gossypol and tannins. However, with the exception of okra leaf shape, for example, which provides moderate resistance to spider mites (Wilson, 1994), few traits have been moved into commercial cultivars and the development time of doing so pales in comparison to the modern transgenic methods that have produced Bt cotton (Jenkins and Wilson, 1996). In any case, the widespread adoption of $B t$ cottons has altered some pest management practices. For example, the emergence of plant bugs as more problematic pests in $B t$ cotton in various countries has placed greater emphasis on the use of control options for these pests that are efficacious but more selective. In Australia, effort has focused on reduced rates of insecticides combined with salt (Khan et al., 2006) or petroleum spray oils (Mensah et al., 2004) for control of mirids. These mixtures have shown considerable promise as they are almost as efficacious, more selective and less expensive than the full rate of the insecticide. In the USA, several new putatively selective, foliar insecticides with reduced-risk profiles (e.g., flonicamid, metaflumizone) are being evaluated for control of Lygus spp. (Ellsworth and Barkley, 2005; Cook et al., 2007) and continued efforts to develop area-wide IPM programs for Lygus spp. based on weed control (Snodgrass et al., 2006) and spatial arrangement of affected crops (Carrière et al., 2006) are underway. Likewise, in China increased focus on weed control and on better management of source crops such as alfalfa are being employed to better manage mirid plant bugs (Wu and Guo, 2005). In India, intercropping cotton with sorghum and pigeonpea is practiced by farmers to help reduce insect damage, and small areas use applications of $H$. armigera NPV and $B t$ - and neem-based insecticides for control of target and non-target pests (Sharma, 2005).

The use of $B t$ cotton may influence other pest control tactics or production issues. For example, in Australia the higher fruit retention of dual gene $B t$ cotton has led to earlier maturity (2-3 weeks) with similar yields to conventional crops. This has 
allowed growers to plant later into warmer conditions that are more favorable to plant growth and reduce risks from disease (Anderson and Nehl, 2006) and early season pests such as thrips. Another example is the opportunity for more 'site-specific' management. Helicoverpa spp. numbers often necessitate a whole farm insecticide application, which decimates natural enemy populations and increases risk of secondary pest outbreaks in Australia. However, the reduced need for control of Helicoverpa spp. in Bt cotton has allowed other pests to be controlled often on smaller portions of the farm resulting in unsprayed fields serving as refuges for natural enemies that can consequently re-colonize sprayed fields. Finally, $B t$ cotton may be used to support conventional cotton crops. Mensah and Macpherson (2006) showed that use of the moth attractant 'Magnet ${ }^{\circledR}$ ' applied to $B t$ cotton with an insecticide (attract and kill) can reduce insecticide costs for Helicoverpa spp. control on nearby conventional cotton. Overall, the use of $B t$ cotton has permitted growers to allot more time and effort into other crop production issues such as nutrition and irrigation optimization leading to improved yields in both $B t$ and conventional fields.

\subsubsection{Resistance Management}

Despite the high adoption rate of $B t$ crops in general, there have not been any reported cases of field failures due to resistance by insects to the Cry proteins since their initial commercial deployment in 1996 (Tabashnik et al., 2003; Mahon et al., 2007; but see Matten et al., chapter 2 for a recent case of putative field resistance to $B t$ maize). Nonetheless there is broad agreement that the sustainability of transgenic $B t$ cottons is one of the most important issues facing cotton insect management and alleles for resistance, and potential resistance mechanisms have been identified in laboratory cultures or field-derived strains of several target pests (e.g., Tabashnik et al., 2003; Gunning et al., 2005; Li et al., 2007; Mahon et al., 2007; Tabashnik et al., 2008). The topic of resistance management is covered in detail by Ferré et al. (chapter 3) for all transgenic crops but some specific information relative to cotton will be highlighted here.

The sustained efficacy of $B t$ toxins against target pests in transgenic cotton can be partly attributed to mandated resistance management programs based around refuge crops and other mitigation approaches in some countries. These programs primarily focus on the key targets (Helicoverpa/Heliothis spp. and P. gossypiella) but potentially delay and mitigate development of resistance in all Bt-susceptible pests. The principle behind all refuge strategies is that non-Bt cottons or other suitable crop or wild hosts produce susceptible target pests that can readily interbreed with any resistant pests that may arise from $\mathrm{Bt}$ fields, thereby diluting incipient resistant alleles from the population.

In most countries, growers must abide by legally binding agreements imposed when purchasing the $B t$ cotton seed. In the USA, Mexico, Colombia, and South Africa growers can adopt several options including planting 5\% non $\mathrm{Bt}$ that generally cannot be sprayed for caterpillar pests, or $20 \%$ non- $B t$ that can be sprayed for caterpillars (but no Bt sprays can be used). These percentages are based on the 
total amount of all cotton planted. In the USA two additional options for embedding 5\% non- $B t$ within a $B t$ cotton field are available where the whole field can be sprayed as needed for any pests (USEPA, 2007). Most requirements also call for the separate $5 \%$ and $20 \%$ refuge plantings to be within $0.5-1.6$ linear $\mathrm{km}$ of the $B t$ crop. These distance requirements are based on an understanding of the dispersal behavior of the target pest and attempt to ensure that mating will occur between resistant and susceptible moths (e.g., Tabashnik et al., 1999). The 5\% refuge option generally dominates in all these countries. Just recently, the USEPA (US Environmental Protection Agency) approved the use of natural refuges (weeds, alternate crops) hosting bollworm/budworm for growers of dual gene Bollgard II cotton in place of the structured refuges outlined above for single gene $B t$ cottons. This approach is much like that practiced in China (see below) and is based on the rationale that sufficient susceptible moths of the polyphagous Helicoverpa/Heliothis spp. can be generated from nearby native vegetation rather than from non-Bt cotton planted as a refuge. These natural refuges are allowed from Texas (excluding farwest and northern tip of the panhandle) to the east coast (but excluding southern Florida), but not in excluded areas of Texas and west to California where the monophagous pink bollworm is the main target. In Argentina and Brazil, where only single gene cottons are available, only the $20 \%$ non- $B t$ refuge is an option and in Brazil this refuge must be within $0.8 \mathrm{~km}$ of the $B t$ cotton. $B t$ maize was provisionally approved in Brazil in mid-2007, but commercial production of the crop awaits review by the Brazilian National Biosafety Council. Further changes in refuge requirements may occur in Brazil if $B t$ maize is eventually approved for commercial cultivation (CTNBio, 2005).

In Australia, the use of cottons containing a single Cry protein (Ingard) was highly restricted with a cap of $30 \%$ of the cotton hectarage. With the introduction and now exclusive use of dual gene Bollgard II, a formal plan with a variety of options was initiated (Farrell, 2006). Growers can choose from 100 ha of non- $B t$ that can be sprayed for bollworms (but no Bt sprays), 10 ha of non- $B t$ that cannot be sprayed for bollworms, or the use of varying amounts (5-20ha) of other refuge crops that host bollworms such as pigeon pea, sorghum or maize for every 100 ha of $B t$ cotton planted. Refuge crops must be within $2 \mathrm{~km}$ of the $B t$ cotton they are meant to protect. The use of 5 ha of unsprayed pigeon pea for every 100 ha of $B t$ cotton is the dominant option employed by most growers as this minimizes the area lost to cotton production. The Australian program also calls upon four additional elements to lessen the risk of resistance including defined planting windows to reduce the period of exposure of $H$. armigera to Bollgard II by avoiding late planted crops, mandatory cultivation of crop residues to destroy diapausing $H$. armigera pupae which may carry resistance between seasons, defined spray thresholds for Helicoverpa spp. (see above) to control potentially resistant survivors in the crops, and control of volunteers of $B t$ cotton in conventional crops and vice versa to reduce the risk of in-field mosaics which increase resistance risk (Fitt and Wilson, 2000).

Resistance management programs are more difficult to implement in China and India because of the challenges associated with educating and monitoring the compliance of the millions of small hectarage cotton farmers in these countries. In 
China, wheat is the main host of first-generation $H$. armigera larvae, and cotton, maize, peanut, vegetables and soybean are the major host plants of subsequent generations. The presence of these crops provides a refuge for susceptible bollworm moths over the entire cotton-growing season, and forms the basis of the recommended resistance management strategy. Nonetheless, the size and type of these natural refuges in different provinces is highly variable and provide differing levels of efficacy (Wu et al., 2002a, 2004). In India, permission for environmental release of $B t$ cotton was predicated on farmers providing a "belt" of surrounding non- $B t$ cotton as a refuge. The size of the belt is $20 \%$ of the $B t$ crop or five rows of non-Bt cotton on the edge of the $B t$ field, whichever is larger. Adherence to these guidelines is generally poor. Manjunath (2005) and Dhillon and Sharma (2007) argue that, much like the situation in China, there are sufficient alternate bollworm hosts present (chickpeas, pigeon pea, sorghum, tomato) to fulfill the refuge requirement without active participation by growers. Likewise, the large numbers of wild alternate host plants for some of the key target pests in South Africa may contribute to resistance management in that country's small hectarage of Bt cotton (Green et al., 2003).

In addition to use of refuge and other tactics for pre-empting resistance, several countries have active programs to monitor for the development of resistance in target pests to $B t$ toxins and/or have developed baseline toxicity to various Cry proteins (Dennehy et al., 2004; Kranthi et al., 2005; Wu et al., 2006; Ali and Luttrell, 2007; Blanco et al., 2007; Mahon et al., 2007; Wu, 2007a). Although resistance to Cry toxins has been selected for in laboratory cultures of all major target species, the frequency of resistant individuals or known resistance alleles have been mostly rare throughout the world and there have been no instances of control failures due to resistance to $B t$ cottons to date. In Australia, the estimated frequency for alleles conferring resistance to Cry1 Ac is $<0.0003$ with a $95 \%$ credibility interval (CI) between 0 and 0.0009 . In contrast, the $R$ frequency for alleles conferring resistance to Cry2Ab2 is over 10x higher at 0.0033 with a $95 \% \mathrm{CI}$ between 0.0017 and 0.0055 (Mahon et al., 2007). Resistance to Cry2Ab2 appears to be recessive but more work is needed to define its inheritance pattern. As a result, the Australian system is strongly dependent on dual gene $B t$ cottons for resistance management. Likewise, the resistance recently documented in field populations of $H$. zea to Cry1Ac in parts of the USA point to the important role of dual gene $B t$ cottons and other management tactics for effective control and resistance management of this pest (Tabashnik et al., 2008).

Remediation plans to deal with potential resistance episodes have been developed in several countries. For example, in the southwestern USA the industry and scientific community have developed a detailed, multi-pronged action plan for the pink bollworm (Arizona Bt Cotton Working Group, 2002). The first step involves routine monitoring by the scientific community or the grower as noted above. If a $\geq 3 \%$ boll infestation with large larvae is detected the plant is then tested to verify it is producing Cry toxins and the larvae are bioassayed to determine if their susceptibility is below a baseline standard (Simmons et al., 1998). If these burdens are met then alternative pink bollworm control measures (e.g., insecticides) are implemented immediately in the target field and further actions such as crop 
termination, and early plow-down with shredding and discing of stalks are implemented to reduce the number of insects potentially surviving to the next season. Surrounding fields are then monitored more carefully and if the same criteria are met in these fields then remedial control actions are implemented as well. The perimeter for remedial action expands accordingly. Only non- $B t$ cotton is subsequently allowed in the remediation zone until resistance has declined to an acceptable level defined by the collective experience of the working group.

Similarly, in Australia reports of larvae in commercial Bt cotton fields are followed up with collections of larvae, which are tested for resistance to both Cry1Ac and Cry $2 \mathrm{Ab} 2$ proteins, and tissues from the plant of origin and from adjacent plants are evaluated for levels of $B t$ protein expression. Each year the results from the monitoring program are extensively reviewed by the Transgenic and Insecticides Management Strategies Committee (consisting of researchers and industry representatives) along with information on refuges and $B t$ cotton use rates, so that the effectiveness of the resistance management plan can be assessed. A change in resistance levels would lead to a revision of the resistance management plan which could result in reinstatement of a cap on the proportion of Bt cotton, an increase in refuge requirements, or both.

\subsubsection{Farm and Landscape Scale Management}

Many IPM programs developed for cotton pests focus on what Kogan (1998) refers to as Level I, or approaches aimed at a single pest species or species complexes on a single crop. To some extent, this situation in cotton has been brought about by the need to manage one or a few key pests, often for which selective insecticides or other tactics were few or lacking. This makes development of practical IPM systems challenging. However, more recent IPM strategies are being developed and practiced that focus on higher levels of integration targeting multiple pests within a whole farm context (e.g., Ellsworth et al., 1998; Wilson et al., 2004). In countries like Australia and the USA the advent of more selective insecticides for control of the Helicoverpa/Heliothis complex has allowed development of more multi-pest based approaches (see above). The availability of $B t$ cottons has provided a further tool on which to build more inclusive IPM strategies by dramatically and selectively reducing the need to control these primary pests.

However, as emphasized before, the use of selective insecticides or $B t$ cotton represents only a few of many tactics that can be melded into a robust IPM strategy. More resilient IPM systems also entail looking at farm operations and management on a year round basis (Wilson et al., 2004). For example, cultivation can kill diapausing resistant Helicoverpa spp. pupae. Cropping rotations can improve soil fertility and soil structure, but also may increase risks of crop diseases and provide overwintering hosts for key pests. Thus, a longer-range view accounts for the effects of farm operations on subsequent pest risks. 
It also is important to consider the links between agronomic management and IPM. For instance, use of high fertilizer rates may increase yield (up to a point), but also may delay crop maturity, increasing the crop's exposure to pests and thereby increase costs and risks. Similarly, late irrigation, beyond that required to finish maturation of bolls, also risks excessive late growth, making crops more attractive to pests and more difficult to defoliate.

Another consideration is the landscape in which Bt cotton is planted (Storer et al., chapter 10). For example, it is sensible to use $B t$ cotton in more sensitive areas, such as near neighbors or rivers, where the reduced need for insecticides can lower the risk of off-site movement. Similarly, but at the larger scale, it is important to consider the activities and layout of neighboring farms with regard to issues like spray drift that may disrupt beneficial populations or cultivation of crops that produce large numbers of a key cotton pests (e.g., safflower and mirids in Australia, alfalfa and Lygus spp. in the USA). At this scale, formation of IPM or area wide management groups may help growers to communicate and reduce risks from such challenges. At even higher scales, coordinated efforts across a region may be effective in reducing pest populations. For example, in the mixed cropping regions of the Darling Downs region of southern Queensland, Australia, an area-wide strategy was established to manage H. armigera populations (Ferguson and Miles, 2002). This approach provided a framework to coordinate efforts to manage the pest across the region by using an understanding of pest ecology to reduce their abundance. Within these frameworks, the deployment of $B t$ cotton plays a critical role by providing broad-scale and selective control over a wide area. Further evidence of the area-wide benefits of $B t$ cotton production is exemplified in the southwest growing areas of the USA where the wide scale use of $B t$ cotton since 1996 has dramatically reduced regional populations of pink bollworm, the main $B t$ cotton target in this area (Carrière et al., 2003). In contrast, several area-wide programs implemented for this pest over the past decades, based on pheromones and insecticides, have never approached such broad and significant population reductions (Henneberry and Naranjo, 1998). In addition, the dramatic reductions in insecticide use for all pests in Arizona cotton (Ellsworth et al., 2007) is in part due to adoption of $B t$ cotton by Arizona growers. Bt cotton also is the center-piece technology of an on-going program to eradicate the pink bollworm from its current range in the western USA and northern Mexico (El-Lissy and Grefenstette, 2006).

\subsection{Environmental Considerations}

Various environmental issues are associated with the use of genetically modified crops including changing patterns of pesticide use (see Fitt, chapter 11 for more detail) and potential effects on animal and plant communities where these crops are grown. Additional detail on these latter topics is provided by Storer et al. (chapter 10) and Romeis et al. (chapter 4). 


\subsubsection{Non-Target Arthropods}

Despite the long history of safety associated with the topical use of $B t$ endotoxins (Glare and O'Callaghan, 2000; Federici, 2003), the season-long expression of these toxins in crop plants through genetic transformation has prompted considerable research to address ecological concerns such as effects on non-target organisms, particularly arthropods. Three countries (Australia, Mexico, and USA) also grow herbicide-tolerant cotton either solely or in combination with $B t$ toxins and these occupy a relatively large share of the GM cotton planted in these countries. There has been relatively little non-target research on herbicide-tolerant cotton and that topic will not be addressed here. However, the vast majority of herbicide-tolerant crops have been modified to be resistant to glyphosate, and there is very little evidence to indicate direct adverse effects of this herbicide on arthropods (Franz et al., 1997).

The effects of pesticide-incorporated crop plants on non-target arthropods have recently been reviewed by O'Callaghan et al. (2005) and Romeis et al. (2006), and the interested reader is referred there for a broader discussion. Bt cotton exerts varying effects on non-target organisms, but the results of a recent meta-analysis indicates that overall impacts on arthropod communities appear to be significantly less than those of the insecticide applications that the GM cotton has reduced (Marvier et al., 2007). Numerous studies have examined the potential effects of $B t$-transgenic crops on natural enemy communities (see Romeis et al., 2006). Not surprisingly, Bt-transgenic crops generally tend to adversely affect specialist parasitoid populations by reducing host abundance (a goal of all pest management tactics) and/or reducing individual fitness through indirect host-mediated effects within $B t$ susceptible hosts. Studies utilizing $B t$-resistant hosts as a means of delivering Cry toxins to parasitoids indicate no direct effect of $B t$ on these natural enemies (Schuler et al., 2004).

Predators are much less affected by $B t$-transgenic crops. Numerous long-term, large-scale field studies have indicated that there are no meaningful impacts of $B t$ cotton on predator populations (Naranjo et al., 2005) and detailed assessments of predator life histories and function underscore these population-level results, indicating no evidence for direct adverse effects of $B t$ toxin on individual predators (see Romeis et al., 2006). Bt toxin can be acquired by predators from $B t$ cotton through prey, but this has not been found to translate into direct negative effects (Torres et al., 2006; Torres and Ruberson, 2006, 2008), and this pattern holds true for other Bt-transgenic crops (Harwood et al., 2005; Obrist et al., 2006a, b). Thus, unlike specialist parasitoids, arthropod predators, most of which are generalists, appear to be little hindered by Bt-transgenic crops.

Few studies have examined the relative biological control capacities of $B t$ and non- $B t$ cotton fields. However, in no case to date has biological control capacity been reduced in $B t$ cotton fields compared to non- $B t$ fields, and biological control has been improved relative to conventionally-managed fields when these have been included in the comparison (Obrycki et al., 2004; Sisterson et al., 2004; Naranjo, 2005; Head et al., 2005; Romeis et al., chapter 4).

There have been very few studies that have examined impacts of $B t$ cotton production on soil communities. However, Lachnicht et al. (2004) found that decomposition 
of $B t$ cotton and non-Bt cotton residues were similar, and Head et al. (2002) reported that Cry1Ac proteins did not accumulate in biologically active amounts in cotton fields after multiple years of $B t$ cotton production. Further, studies by Shen et al. (2006) indicate that microbial communities in the rhizosphere of soils amended with $B t$ and non- $B t$ cotton residue have the same diversity and functional activity. These results are largely consistent with a larger number of soil residue studies that have been completed for $B t$ maize (Sanvido et al., 2007). Overall, impacts of Bt cotton on non-target organisms appear to be limited or negligible, depending on the species and guild, and from a community perspective appear to be significantly less detrimental than most insecticides widely used in cotton pest management. Recent meta-analyses based on the extant literature suggest that these results are consistent among broad taxonomic groups and feeding guilds and should apply to ecologically equivalent taxa worldwide (Marvier et al., 2007; Wolfenbarger et al., 2008).

\subsubsection{Gene Flow}

An additional environmental concern with genetically modified crops is the flow of genes via pollen to non-transgenic counterparts or other closely related species. Cotton is primarily self-pollinated and the pollen is sticky, relatively heavy, and flowers are only open for a single day (Poehlman, 1987). Thus the opportunity for the spread of transgenes to other plants is thought to be limited and existing research seems to bear this out. Llewellyn and Fitt (1996) found that cross pollination of cotton in Eastern Australia was about $10 \%$ or less in adjacent rows $1 \mathrm{~m}$ apart. Insect vectored movement in pollen is possible and honey bees have been implicated in moving pollen, however this is only considered a risk if bee numbers are high (Llewellyn et al., 2007). In Northern Australia, movement of pollen was higher than in Eastern Australia, which was attributed to higher bee density. These authors concluded that buffers of $20 \mathrm{~m}$ of conventional cotton are adequate to contain cross pollination unless bee numbers are high. The risk of transgenes escaping into wild cottons is extremely low (Brubaker and Brown, 2002; Constable et al., 2007). This is largely because most wild Gossypium are diploid, while cultivated cotton is a tretraploid. Cotton volunteers can be found outside of cotton farms, however, Eastick and Hearnden (2006) found that Bt cotton does not have the potential to be weedier than conventional cotton. The risk of transgenic cotton becoming a roadside weed, or a weed on dairy farms where raw seed is used as feed also was found to be extremely low (Addison et al., 2007) because the main factors limiting establishment and growth of cotton in these environments were environmental (frost, water, grazing) and the transgenes offered no advantage.

Autoimmunity acts as a potential gene flow barrier in several plant species, including the diploid $G$. arboreum, and the tetraploid, $G$. hirsutum and $G$. barbadense cottons (Bomblies and Weigel, 2007). Thus, no interspecific hybrids have been observed between cultivated cottons and closely related wild relatives in India. Even if a small amount of gene flow occurs, there is little chance that the resulting interspecific hybrids will survive. Similarly, there is little risk of gene flow 
between $B t$ cotton and wild cotton in China because it is not a native country of wild cottons (Jia, 2001). Recent studies in the USA have suggested that gene flow from $B t$ cottons may occur at low levels resulting in the production of small amounts of fruit in adjacent non- $B t$ cotton plants producing $B t$ toxins (Heuberger, 2006). Patterns appear to be independent of distance from potential sources at least over relatively small scales, but the implications of this for resistance management are currently poorly understood.

\subsubsection{Change in Insecticide Use}

As highlighted throughout this chapter, one of the most obvious changes in production practices with the introduction of $B t$ cotton has been insecticide use patterns in most adopting countries (also see Fitt, chapter 11 and Qaim et al., chapter 12). On a global scale, Brookes and Barfoot (2006) estimated that Bt cotton production during the period 1996-2005 has reduced the total volume of insecticide active ingredient use by 94.5 million kilograms. This represents a $19.4 \%$ reduction and was the largest reduction in pesticide use afforded by any GM crop. Moreover, if aspects of the environmental toxicity of the insecticides used are accounted for through the environmental impact quotient (EIQ; Kovach et al., 1992), there was a $24.3 \%$ reduction in this quotient over the 10 year period indicating that not only was overall insecticide use reduced but so was their overall environmental impact by an even larger margin. The USA (23\%), China (28\%) and Australia (22\%) realized the largest reductions in EIQ, while countries like Argentina and India had reductions of $<4 \%$ during the period 1996-2005. In developed nations such as Australia and the USA, changing insecticide use patterns are closely followed by the industry. In the USA there has been an overall reduction in insecticides used for all pests (Fig. 6.2), which has resulted from a combination of factors including the introduction of newer insecticides, the near eradication of the boll weevil (historically one of the most significant pest of cotton in the USA), better adherence to IPM practices, and use of $B t$ cotton. Even with $B t$ cotton, the bollworm/budworm complex remains dominant. Emerging pests like plant bugs and stinkbugs are becoming more of a focus of pest management, and while there has been a significant decline in insecticides for bollworm/budworm there has been a slight but correlated increase in insecticides for these bug pests (Fig. 6.2).

Likewise, in Australia there has been a steady decline in insecticide use since the introduction of $B t$ cotton (Ingard), and insecticide use in Bollgard II cotton is about 75\% less than in conventional cotton (Fig. 6.3). This has had obvious benefits in terms of risks of off-farm movement and human health. An additional benefit has been that levels of resistance in H. armigera, spider mites and aphids to conventional insecticides in non-Bt cotton have also declined (Herron and Wilson, 2006; Rossiter and Kauter, 2006), presumably due to less spraying and the huge sink effect of large areas of Bollgard II cotton, combined with prolonged drought ensuring few alternative hosts. 


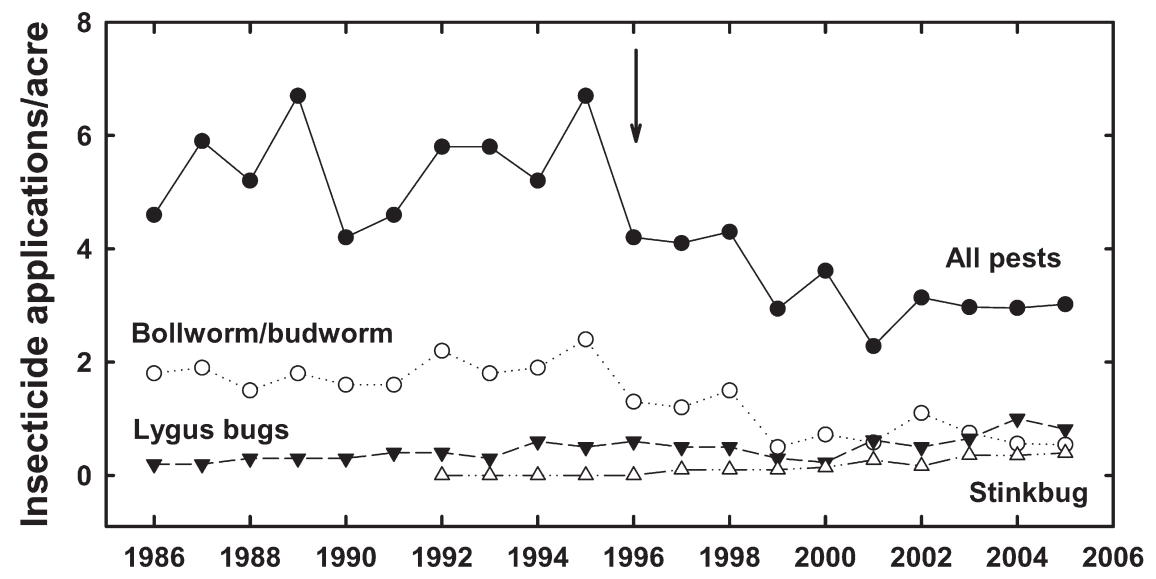

Fig. 6.2 Insecticide use patterns in the USA 1986-2005 relative to all pests, major caterpillar pests and two $B t$ cotton non-target pests that have increased in importance with the production of $B t$ cotton. Arrow denotes the beginning of $B t$ cotton production (Compiled from data of the National Cotton Council, http://www.cotton.org/tech/pest/index.cfm)

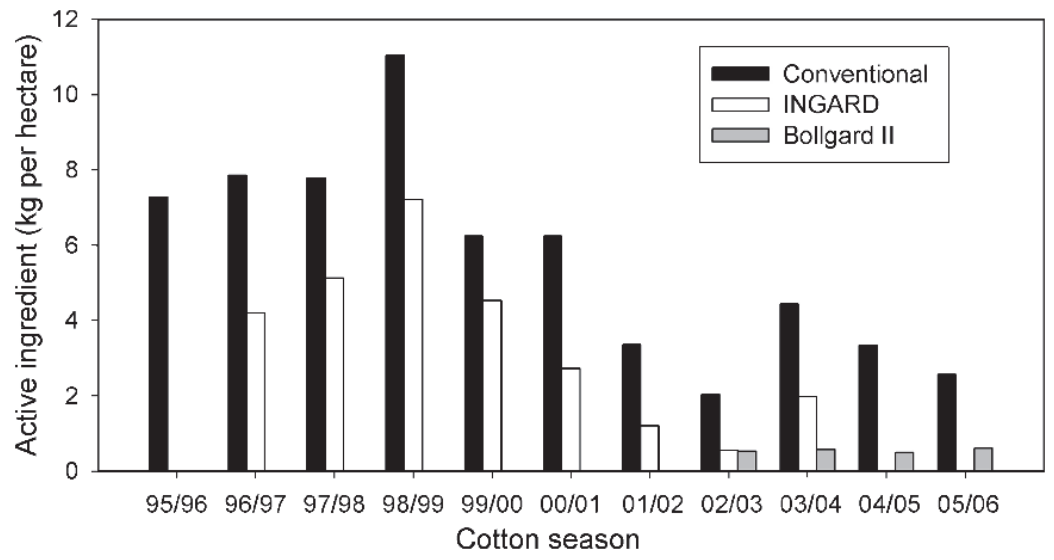

Fig. 6.3 Insecticide use patterns in Australia 1995-2006 for all pests; $B t$ cotton production started in the 1996/97 season (Derived from Pyke, 2008 using data extracted from the Cotton Consultants Australia Market Audit Reports 1998-2006)

Large reductions in insecticide use have also been observed in various developing nations that have adopted $B t$ cotton (Raney, 2006). Based on recent data compiled over two to three growing seasons it is estimated that insecticide costs have been reduced by 47\%, 67\%, 41\%, 77\% and 58\% in Argentina, China, India, Mexico and South Africa, respectively. These reductions in insecticide usage also have been 
accompanied by gains in yield, revenue and overall profit in these same countries (see below). In China, resistance in $H$. armigera to commonly used insecticides led to instances in which more than 20 applications were made per season to control this pest in the early 1990s. The adoption of $B t$ cotton shifted this pattern dramatically despite a trend for increasing insecticide use for plant bug control (Pray et al., 2001; Wu, 2007b).

\subsection{Adoption and Use}

It is often noted that GM crops have been one of the most widespread and rapidly adopted agricultural technologies in history. However, each adopting country has had to struggle with fundamental issues of regulatory authority, environmental and food safety, intellectual property rights, societal demands and other factors governing the production and economics of such crops within their borders. These issues are covered in some detail in other chapters of this book. Here we briefly highlight some of these issues relative to $B t$ cotton.

\subsubsection{Regulation}

Each country growing GM crops has had to grapple with regulatory issues, with some countries adapting existing governmental organizations to serve these needs and others developing new organizations and authorities (see Matten et al., chapter 2). For example, in the USA various aspects of GM crop regulation are handled by a coordinated framework of three government entities, US Environmental Protection Agency (USEPA), United States Department of Agriculture (USDA) and the Food and Drug Administration (FDA), which oversee pesticide safety, food safety, and movement and transport of seed, respectively (Herdt, 2006). In India, the Ministry of Environment \& Forests deals with regulatory issues but calls upon other scientific and policy based entities for safety testing, approval for commercial release, and monitoring. In China, the Ministry of Agriculture oversees the implementation of regulations dealing with safety assessment, production, import, labeling, and processing of GM cotton. In Australia, research and commercial release of transgenic cotton is handled by the Office of the Gene Technology Regulator. However, other agencies also are involved in granting registration, most significantly Food Standards Australia and New Zealand and the Australian Pesticide and Veterinary Medicines Authority. The Brazilian National Biosafety Technical Commission within the Brazilian Federal Science and Technology Department oversees approval of GM crops in that country and the GMO Act in South Africa enabled the establishment of institutions for evaluation and approval. The fact that cotton is primarily a non-food crop has simplified regulatory issues in some countries. 


\subsubsection{Economics}

The economic costs and benefits of $B t$ cotton have been reported by a number of sources over the past decade of adoption (reviewed in Shelton et al., 2002; Brookes and Barfoot, 2006; Smale et al., 2006; Qaim et al., chapter 12) and, much like the general topic of GM crops, the subject is tangled in some controversy (e.g., Benbrook, 2003; Shiva and Jafri, 2003; Pschorn-Strauss, 2005). Nonetheless the bulk of published information shows positive economic benefits associated with the production of $B t$ cotton across a broad cross-section of the industry. A recent synopsis by Brookes and Barfoot (2006), which compiled data over a large number of country-specific, farm-scale studies, indicates that over the 10 year period from 1996-2005, Bt cotton production has increased farm income globally by US $\$ 7.51$ billion. This represents approximately $6.7 \%$ of the value of all cotton production worldwide. The largest benefactors, in absolute terms, have not surprisingly been the nations with the greatest adoption and production capacity like China, India and the USA (Table 6.4). Also not surprising given this distribution, in 2005 nearly $80 \%$ ( $\$ 1.38$ billion) of the income benefits were garnered by farmers in developing nations. Using a multi-region, equilibrium model approach, Frisvold and Reeves (2007) have suggested a global economic benefit of almost $\$ 1.4$ billion from world Bt cotton production based on 2005 adoption rates despite an estimated 3\% decline in world cotton prices due to increased production. Several studies indicate that a significant portion of the overall economic benefits of $B t$ cotton accrue to producers while only a relatively small portion benefits biotechnology firms and seed companies, especially in developing nations (Price et al., 2003; Gouse et al., 2004; Traxler and Godoy-Avila, 2004).

Raney (2006) suggests that GM crops in general, and Bt cotton in particular, may benefit the small, resource-poor farmer more than it does large growers through enhancement of yield and reductions in costs and health-related issues associated with insecticide use. However, such associations may not always be clear cut. For example, Shankar and Thirtle (2005) studied small farmers in the Makhathini flats of South Africa and found that the bulk of the positive gains through the adoption of $B t$ cotton has been realized through gains in yield and not insecticide cost saving since relatively few insecticides are used by growers in this region even in the face of heavy insect pest pressure. Such effects are masked in country-wide analyses that pool results from large and small farm operations. Substantial yield gains for $B t$ cotton in other developing countries may follow a similar pattern because pest control in conventional cotton is relatively poor. On the contrary, the relatively small gains in yield observed by adopters of $B t$ cotton in Australia, China and the USA (Table 6.4) arise because growers in these countries engage in aggressive and effective pest control in conventional cotton. In these instances, $B t$ cotton is simply a substitute for insecticides targeting lepidopteran pests. In any case, it is important to consider that not all yield effects may be tied to $B t$ cotton per se. The varieties and hybrid producing $B t$ toxins may be better adapted than non- $B t$ cottons grown in the same area (e.g., Qaim et al., 2006), growers 
Table 6.4 Estimated economic impacts of Bt cotton production 1996-2005

\begin{tabular}{lllll}
\hline & $\begin{array}{l}\text { Farm income benefits } \\
\text { (US\$ million) }\end{array}$ & $\begin{array}{l}\text { Yield effects } \\
(\%)\end{array}$ & $\begin{array}{l}\text { Technology fee } \\
(\text { US } \$ / \text { ha })\end{array}$ & $\begin{array}{l}\text { Cost savings fee } \\
\text { excluding (US \$/ha) }\end{array}$ \\
\hline Argentina & 29 & 24 & $40-86$ & 18 \\
Australia & 150 & 0 & $138-250$ & $151-553$ \\
China & 5,168 & $8-10$ & 46 & $261-438$ \\
India & 463 & $45-64$ & $62-66^{\mathrm{a}}$ & $31-66^{\mathrm{a}}$ \\
Mexico & 55 & $3-37$ & $49-65^{\mathrm{a}}$ & $90-121^{\mathrm{a}}$ \\
South Africa & 14 & 24 & $53^{\mathrm{a}}$ & $18^{\mathrm{a}}$ \\
USA & 1,627 & $9-11$ & $58-68$ & $63-74$ \\
\hline
\end{tabular}

From Brookes and Barfoot (2006); ranges represent varying estimates over time. Data not currently available for Colombia and Brazil

${ }^{a}$ Values converted from local currency to US dollars based on exchange rates on 31 July 2007

adopting $B t$ cottons may be more efficient farmers overall, and they may grow $B t$ cotton (for which a premium is paid) on their best land and under more optimal conditions (Kambhampati et al., 2006).

The adoption of $B t$ cotton in all countries is closely tied with the perceived or actual benefit of its production balanced against the technology costs imposed universally by providers of the seed and GM traits. These technology fees can vary widely across the world and can even vary within individual countries depending on the level of government involvement and/or other marketing forces (Table 6.4). Australian growers pay the largest fees to access $B t$ technology, but they also reap the largest rewards on a per hectare basis and have among the highest adoption rates in the world. On the contrary, the relatively high technology fee in Argentina has been credited with keeping adoption rates very low in this country (Qaim and DeJanvry, 2005). In China, the government has invested heavily in development of GM crops and this competition helps to keep technology fees low (Raney, 2006). A dualistic system in South Africa which provided credit to resource-poor farmers to acquire the technology initially led to high adoption rates, but this was not sustained when credit became difficult to secure due to changes in local cotton cooperatives (Raney, 2006). In the USA, technology fees vary widely across cotton producing states based on various market forces with fees generally highest in western states (Frisvold et al., 2006).

Additional economic and environmental benefits have been accrued via reductions in fuel costs for growers and reductions in greenhouse gas emissions because of less frequent use of tractors for pesticide application and other cultivation operations (Brookes and Barfoot, 2006).

\subsubsection{Social Issues}

$B t$ cotton was the first GM crop commercialized in many parts of the world and as of late 2007 remains the sole insect resistant transgenic crop commercially grown in Australia, Brazil, China, Colombia, India and Mexico (James, 2007), although 
Brazil is currently considering the commercial cultivation of $B t$ maize. Its relatively ready acceptance in most countries was related to its primary use as a non-food crop, but its adoption has not been without controversy. There has been strong and vocal opposition to GM crops in general by such non-governmental organizations as Greenpeace, the Union of Concerned Scientists, and more localized opposition exemplified in countries like India which despite the capacity to produce $B t$ cotton for several years did not approve commercial production until 2002 (Jayaraman, 2001, 2002). Critics claim that adoption of Bt cotton in India benefits multi-national biotechnology companies while hurting small farmers because of the additional investments needed to grow the new Indian $B t$ hybrids successfully, and the risk of resistance to $B t$ in major pest species. Proponents counter that farms of all size benefit from the technology and note that compliance with refuge requirements to thwart resistance is not critical because adoption is likely to be far from universal. Proponents point to the large success of Bt cotton in small-farmer dominated China, while critics offer the example of the short and unsuccessful experience of Bt cotton in Indonesia. The overall controversy has been further exacerbated by unscrupulous seed companies and over-eager farmers selling and growing $B t$ cotton before commercial approval had been given in countries such as India, Pakistan and Brazil (Jayaraman, 2001; Ilyas, 2004; Ewing, 2005). The extent of use of so called "stealth seed" prior to official release of $B t$ cotton in India, and its current use in the country is very difficult to gauge, but some estimates put the figure at $>50 \%$ and it could be higher in certain Indian states (Herring, 2007). Sales of illegal Bt cotton seeds have misled and confused farmers and resulted in problems with seed purity, performance, and bio-safety. Bennett et al. (2005) compared the performance of officially released and unofficially cultivated hybrid varieties of $B t$ cotton and conventional hybrids in Gujarat, India by 622 farmers, and observed that the officially released $B t$ varieties outperformed the unofficial varieties. However, unofficially produced $B t$ hybrids also performed better than the non- $B t$ hybrids, although the second generation $\left(\mathrm{F}_{2}\right) B t$ seed had no yield advantage over the non- $B t$ hybrids. $\mathrm{F}_{2}$ seed is regarded as 'GM' by the farmers (and is sold as such), even though its yield performance is little better than the non-Bt hybrids. The issue of illegal seed is being aggressively addressed in India and elsewhere, but there seems little doubt that significant debate will continue to embroil the development and adoption of many aspects of GM crops throughout the world.

\subsection{Future Developments}

Many tactics within the cotton IPM toolbox will continue to be developed, improved, refined, and integrated into strategies that address the interests of producers and society, and positively impact the environment. Host plant resistance, now more and more the product of biotechnological advances, will continue to be a key element in future IPM systems for cotton and many other crops. The promise of transgenes to help solve long-standing pest problems and perhaps other agronomic issues is great 
and with proper forethought, and scientific, governmental and public guidance and scrutiny should continue to revolutionize IPM and crop production.

\subsubsection{New Events}

As noted, commercial insect-resistant transgenic cottons are currently limited to various transgenes from $B$. thuringiensis producing $\delta$-endotoxins (see Table 6.1). VipCot cotton (Syngenta Biotech) will express the Vip3A vegetative protein from B. thuringiensis, probably in combination with a Cry protein, and is expected to be commercialized in the USA and Australia shortly (Malone et al., chapter 13). As with current Cry endotoxins in cotton, the range of effects of ViP3A is restricted to Lepidoptera and non-target effects appear minimal (Whitehouse et al., 2007). The dual gene cotton WideStrike (Dow AgroScience), which expresses Cry1Ac plus Cry $1 \mathrm{~F}$ and has been available in the USA since 2005, will likely be introduced into Australia in the near future. Bollgard II was commercialized in the USA in 2003, in Australia in 2004 and has recently been approved for use in India. In general, the dual gene constructs have improved efficacy against the primary targets of single gene events and improved efficacy against troublesome pests such as Spodoptera spp. among other caterpillars. Technology fees are greater but production will continue to expand so long as the farmers see a significant economic gain. In late 2007, Australia approved limited field evaluation of transgenic G. barbadense (long-staple cotton) that produces Cry1 Ac and Cry2Ab with or without additional genes for herbicide tolerance. Bollgard III (Hybrid Cry1Ac and Cry1F plus Cry 2Ab) from Monsanto aims to further increase the spectrum of lepidopteran control and provide better late season control through the use of different promoters and proteins (Monsanto, 2007). Cottons based on this technology are in an early product development phases and are several years away from potential commercialization.

The introduction of other insect-resistant GM crops could have important consequences for the production of $B t$ cotton. As noted, $B t$ cotton is currently the only insect-resistant GM crop grown in many adopting nations. The potential commercialization of $B t$ maize is under consideration in countries such as China and Brazil and could have important implications for resistance management. China in particular relies heavily on conventional maize and other crops to act as refuges for susceptible bollworms to ameliorate resistance in $\mathrm{Bt}$ cotton. The adoption of Bt corn could accelerate bollworm resistance in that country without further planning and oversight.

\subsubsection{Increasing Pest Spectra of GM Cotton}

Lepidopteran pests have been the focus of GM cotton development to date and with good reason given the serious nature of this pest complex worldwide. Nonetheless, a number of other significant pests impact cotton production globally (see Table 
6.3) and improvements in host plant resistance through transgenic approaches may help to manage these pests within an overall IPM framework as well. Glare and O'Callaghan (2000) catalog over 170 distinct $\delta$-endotoxins as well as many other toxins from $B$. thuringiensis that could be mined for future transgenic plant development. Lectins and protease inhibitors are being examined in cotton and other crop species for sucking pests and as additional avenues for control of lepidopteran pests (e.g., Carlini and Grossi-de-Sa, 2002; Christou et al., 2006; Malone et al., chapter 13). Monsanto (2007) is in the very early stages of development of transgenic cottons targeting Lygus spp. based on Bt and non-Bt approaches and the publiclyfunded Center for Plant Molecular Biology in India has developed a lectin gene for control of sucking pests and is set to license the technology to a private Indian company for use in rice and cotton (Jayaraman, 2004; see also Malone et al., chapter 13).

Efforts are underway to improve many other characteristics of the cotton plant to improve production efficiency and market value. For example, the improvement of several agronomic issues such as tolerance to drought and the herbicide dicamba are in the early stages of development (Monsanto, 2007). Advances are also being made in reducing the concentration of the terpenoid gossypol in cotton seed through RNA interference technology so that the protein in this abundant by-product of cotton lint production may have additional food value for humans (Sunilkumar et al., 2006).

\subsection{Summary and Conclusions}

The rate and scale of adoption of $B t$ cotton is unprecedented relative to other advances in production of this crop. In 1996, its initial year of commercial production, approximately 1.1 million hectares were grown in three countries. By 2007, the rate of production had increased 12.7-fold to 14 million hectares in nine countries, and several other countries are likely to adopt or re-adopt the technology in the near future. This rapid adoption by a wide cross-section of growers, large and small, has been largely driven by the significant economic benefits of the technology in reducing production costs while improving yield and quality. The technology also has had dramatic positive impacts on the environment globally through the reduction in insecticide usage and even reductions in fuel consumption and associated greenhouse gas emissions in farm operations in a system that has historically been associated with insecticide over-reliance and misuse.

Although the deployment of $B t$ cotton represents only one of a myriad of tactics that can be integrated into efficient and effective pest management strategies, its contribution via reduction in insecticide usage has the potential to cascade through the system and enhance other integrated pest management tactics such as biological control. Numerous non-target studies both in the laboratory and the field have definitively shown the selective nature of this pest control technology and indicate that enhanced biological control should be possible. Indeed, evidence from systems 
in China and USA has demonstrated the key role of biological control in managing non-target pests in $B t$ cotton. This high degree of selectivity may, however, have some drawbacks. In some systems the use of $B t$ cotton has been associated with increased pressure from other primary or secondary pests not susceptible to $B t$ toxins that may have been previously suppressed by insecticides used for target lepidopteran pest species. In these instances it is likely that effective biological control was absent initially and the selective action of $B t$ has not improved the situation. The adoption of $B t$ cotton has only minor effects on other basic pest management practices such as sampling and use of economic thresholds. Growers may need to be more vigilant of non-target pest dynamics and use modified sampling and threshold protocols for target pests incompletely controlled by current $B t$ cottons. The deployment of $B t$ cotton has the potential to have suppressive area-wide effects on pest populations leading to reduced risk and greater predictability for growers.

To date, resistance to transgenic $B t$ cotton has not been an issue, but constant vigilance and stewardship by all members of the agricultural community will be required to maintain the sustainability of this valuable technology. The use of structured refuges in most countries has been credited with delaying or mitigating resistance but even in countries such as China where resistance management depends on unstructured, natural refuges the technology has been resilient. Sustained pest control also will benefit from future advances in the development of new transgenic events that will improve control efficacy of lepidopteran pests as well as target other key pest species in cotton worldwide. Such advances will rely on continued partnerships between growers, seed and technology industries, and public research institutions. Debate over issues of food and environmental safety, regulatory oversight, and welfare of the farming community as a whole are also likely to continue as the technology moves forward with new crops and new adopting countries.

Acknowledgements We would like to thank Muhammadarshad Awan (Pakistan), Cristina Schetino Bastos (Brazil), Cesar Cardona (Colombia), Jose Martinez-Carrillo (Mexico), Greg Constable (Australia), Eugen Eulitz (South Africa), Graham Head (USA), Joe Huesing (USA), Miguel Serrano (Colombia), Eduardo Trumper (Argentina), and Maurice Vaissayre (France) for their valuable assistance in providing information about $B t$ cotton production in their respective countries and elsewhere.

\section{References}

Abdelrahman, A.A., and Munir, B., 1989. Sudanese experience in integrated pest management of cotton. Insect Science and Applications 10: 787-794.

Adamczyk, J.J., Jr., and Gore, J., 2004. Laboratory and field performance of cotton containing Crylac, Cry1f, and both Crylac and Crylf (Widestrike ${ }^{\mathrm{TM}}$ ) against beet armyworm and fall armyworm larvae (Lepidoptera: Noctuidae). Florida Entomologist 87: 427-432.

Adamczyk, J.J., Jr., Adams, L.C., and Hardee, D.D., 2001. Field efficacy and seasonal expression profiles for terminal leaves or single and double Bacillus thuringiensis toxin cotton genotypes. Journal of Economic Entomology 94: 1589-1593. 
Addison, S., Farrell, T., Roberts, G., and Rogers, D., 2007. Roadside surveys support predictions of negligible naturalisation potential for cotton in north-east Australia. Weed Research 47: 192-201.

Ali, M.A., and Luttrell, R.G., 2007. Monitoring Bt susceptibility in Helicoverpa zea and Heliothis virescens: Results of 2006 studies. In: Proceedings of the Beltwide Cotton Conferences, National Cotton Council, Memphis, TN, USA, pp. 1062-1072.

Anderson, C., and Nehl, D., 2006. Delayed sowing as a best-bet approach to minimise the impacts of Fusarium wilt. In: Proceedings of the 13th Australian Cotton Conference, Australian Cotton Growers Research Association, Narrabri, New South Wales, Australia, pp. 443-446.

Anonymous, 1995. Cotton - the crop and its pesticide market. Pesticide News 30: 1.

Arizona Bt Cotton Working Group, 2002. A Remedial Action Plan for Responding to Pink Bollworm Resistance in Bt Cotton in Arizona. Cooperative Extension, University of Arizona, Tucson, AZ, USA.

Benbrook, C.M., 2003. Impact of genetically engineered crops on pesticide use in the United States: The first eight years. BioTech InfoNet, Technical Paper No. 6.

Benedict, J.H., and Ring, D.R., 2004. Transgenic crops expressing Bt proteins: Current status, challenges and outlook. In: Transgenic Crop Protection: Concepts and Strategies, O. Koul and G.S. Dhaliwal, eds., Science Publishers, Enfield, NH, USA, pp. 15-84.

Bennett, R., Ismael, Y., and Morse, S., 2005. Explaining contradictory evidence regarding impacts of genetically modified crops in developing countries. Varietal performance of transgenic cotton in India. Journal of Agricultural Science 143: 35-41.

Bishop, A.L., and Blood, P.R.B., 1977. A record of beneficial arthropods in South East Queensland cotton. Pest Articles and News Summaries 23: 384-386.

Blanco, C.A., Perera, O.P., Boykin, D., Abel, C., Gore, J., Matten, S.R., Ramirez-Sagahon, J.C., and Teran-Vargas, A.P., 2007. Monitoring Bacillus thuringiensis-susceptibility in insect pests that occur in large geographies: How to get the best information when two countries are involved. Journal of Invertebrate Pathology 95: 201-207.

Bomblies, K., and Weigel, D., 2007. Hybrid necrosis: Autoimmunity as a potential gene-flow barrier in plant species. Nature Reviews Genetics 8: 382-393.

Bottrell, D.G., and Adkisson, P.L., 1977. Cotton insect pest management. Annual Review of Entomology 22: 451-481.

Brookes, G., and Barfoot, P., 2006. Global impact of biotech crops: Socio-economic and environmental effects in the first ten years of commercial use. AgBioForum 9: 139-151.

Brubaker, C., and Brown, A., 2002. An Evaluation of the Potential for Gene Flow Between Commercial Cotton Cultivars and Wild Australian Cotton Species. CSIRO Plant Industry Report.

Carlini, C.R., and Grossi-de-Sa, M.F., 2002. Plant toxic proteins with insecticidal properties. A review on their potentialities as bioinsecticides. Toxicon 40: 1515-1539.

Carrière, Y., Ellers-Kirk, C., Sisterson, M., Antilla, L., Whitlow, M., Dennehy, T.J., and Tabashnik, B.E., 2003. Long-term regional suppression of pink bollworm by Bacillus thuringiensis cotton. Proceedings of the National Academy of Sciences of the USA 100: 1519-1523.

Carrière, Y., Ellsworth, P.C., Dutilleul, P., Ellers-Kirk, C., Barkley, V., and Antilla, L., 2006. A GIS-based approach for areawide pest management: The scales of Lygus hesperus movements to cotton from alfalfa, weeds, and cotton. Entomologia Experimentalis et Applicata 118: 203-210.

Chappell, A.S., Kring, T.J., Lorenz, G.M., Greene, J.K., and Studebaker, G.E., 2005. Reliance on predators in making cotton aphid treatment decisions. In: Proceedings of the Beltwide Cotton Conferences, National Cotton Council, Memphis, TN, pp. 1610-1612.

Chitkowski, R.L., Turnipseed, S.G., Sullivan, M.J., and Bridges, W.C., Jr., 2003. Field and laboratory evaluations of transgenic cottons expressing two proteins compared with one of Bacillus thuringiensis var. kurstaki Berliner for management of noctuid (Lepidoptera) pests. Journal of Economic Entomology 96: 755-762.

Christou, P., Capell, T., Kohli, A., Gatehouse, J.A., and Gatehouse, A.M.R., 2006. Recent developments and future prospects in insect pest control in transgenic crops. Trends in Plant Science 11: $302-308$. 
Constable, G., Preston, C., and Gupta, V., 2007. Genomic age series Part 3: GM cotton - benefits, risks and opportunities. Agricultural Science 20: 28-32.

Cook, D.R., Leonard, B.R., Burris, E., and Burns, D.R., 2007. Tarnished plant bug management in Northeast Louisiana. In: Proceedings of the Beltwide Cotton Conferences, National Cotton Council, Memphis, TN, USA, pp. 1704-1710.

CTNBio, 2005. Commercial use of resistant insect cotton. Proceedings of the Brazilian Federal Biosafety Technical Commission (CTNBio). http://www.ctnbio.gov.br/index.php/content/ view/3663.html (accessed 12 March 2008).

Deng, S.D., Xu, J., Zhang, Q.W., Zhou, S.W., and Xu, G.J., 2003. Effect of transgenic Bacillus thuringiensis cotton on population dynamics of the non-target pests and natural enemies. Acta Entomologica Sinica 46: 1-5.

Dennehy, T.D., Unnithan, G.C., Brink, S.A., Wood, B.D., Carrière, Y., Tabashnik, B.E., Antilla, L., and Whitlow, M., 2004. Update on pink bollworm resistance in Bt cotton in the southwest. In: Cotton, A College of Agriculture Report, Series P-138, University of Arizona, Tucson, AZ, USA, pp. 213-223.

Devine, G.J., Ishaaya, I., Horowitz, A.R., and Denholm, I., 1998. Effects of piperonyl butoxide on Bemisia tabaci Genn. (Homoptera: Aleyrodidae): Mortality, development, parasitism and predation in Israeli cotton fields. Crop Protection 17: 717-726.

Dhillon, M.K., and Sharma, H.C., 2007. Survival and development of Campoletis chlorideae on various insect and crops hosts. Implications for Bt-transgenic crops. Journal of Applied Entomology 131: 179-185.

Dippenaar-Schoeman, A.S., van den Berg, A.M., and van den Berg, A., 1999. Spiders in South African cotton fields: Species diversity and abundance (Arachnida: Araneae). African Plant Protection 5: 93-103.

Doyle, B., Reeve, I., and Coleman, M., 2006. The CCA 2005 Bollgard Comparison Report: A Survey of Cotton Growers' and Consultants' Experience with Bollgard in the 2004-2005 Season. The Cotton Research and Development Corporation and The Cotton Catchment Community Cooperative Research Centre. Institute for Rural Futures, Armidale, New South Wales, Australia.

Eastick, R., and Hearnden, M., 2006. Potential for weediness of Bt-cotton in Northern Australia. Weed Science 54: 1142-1151.

El-Lissy, O.A., and Grefenstette, W.J., 2006. Progress of pink bollworm eradication in the U.S and Mexico, 2005. In: Proceedings of the Beltwide Cotton Conferences, National Cotton Council, Memphis, TN, USA, pp. 1313-1319.

Ellsworth, P.C., 1997. Bt Cotton in Arizona. What Will Change? University of Arizona, Cooperative Extension No. 1 (revised), Tucson, AZ, USA.

Ellsworth, P.C., and Barkley, V., 2005. Transitioning Lygus chemical controls to more selective options for Arizona Cotton. In: Cotton, A College of Agriculture Report, Series P-142, University of Arizona, Tucson, AZ, USA, pp. 165-178.

Ellsworth, P.C., and Martinez-Carrillo, J.L., 2001. IPM for Bemisia tabaci: A case study from North America. Crop Protection 20: 853-869.

Ellsworth, P.C., Naranjo, S.E., Castle, S.J., Hagler, J., and Henneberry, T.J., 1998. Whitefly management in Arizona: Looking at whole systems. In: Cotton, A College of Agriculture Report, Series P-112, University of Arizona, Tucson, AZ, USA, pp. 311-318.

Ellsworth, P.C., Fournier, A., and Smith, T.D., 2007. Arizona cotton insect losses. Publ. No. AZ1183. University of Arizona, College of Agriculture and Life Sciences, Cooperative Extension, Tucson, AZ, USA. Based on P.C. Ellsworth, J.S. Jones and T.D. Smith. 2000. http://cals.arizona.edu/crops/cotton/insects/cil/cil.html (accessed 12 March 2008).

Eveleens, K.G., van den Bosch, R., and Ehler, L.E., 1973. Secondary outbreak induction of beet armyworm by experimental insecticide application in cotton in California. Environmental Entomology 2: 497-503.

Ewing, R., 2005. End of Brazil GMO ban to curb rampant black market. Grain, Barcelona, Spain. http://www.grain.org/research/contamination.cfm?id = 286 (accessed 15 January 2008).

Farm Press, 2006. Delta Agricultural Digest 2006. Farm Press, Clarksdale, MS, USA. 
Farrell, T., ed., 2006. Cotton Pest Management Guide 2006-07. New South Wales Department of Primary Industries, Australia.

Farrell, T., Mensah, R., Sequeira, R., Wilson, L., and Dillon, M., 2006. Key insect and mite pests of Australian Cotton. In: Cotton Pest Management Guide 2006-07, T. Farrell, ed., New South Wales Department of Primary Industries, Australia, pp. 1-17.

Federici, B.A., 2003. Effects of Bt on non-target organisms. Journal of New Seeds 5: 11-30.

Ferguson, J., and Miles, M., 2002. Area wide management on the Darling Downs - has it worked? In: Proceedings of the Australian Cotton Conference, Australian Cotton Growers Research Association, Narrabri, New South Wales, Australia, pp. 711-719.

Fitt, G.P., and Wilson, L.J., 2000. Genetic engineering in IPM: Bt cotton. In: Emerging Technologies for Integrated Pest Management: Concepts, Research and Implementation, G.G. Kennedy and T.B. Sutton, eds., APS Press, St. Paul, MN, USA, pp. 108-125.

Franz, J.E., Mao, M.K., and Sikorski, J.A., 1997. Glyphosate: A unique global herbicide. American Chemical Society Monograph 189, Washington, DC, USA, 653 pp.

Frisvold, G., and Reeves, J.M., 2007. Economy-wide impacts of Bt cotton. In: Proceedings of the Beltwide Cotton Conferences, National Cotton Council, Memphis, TN, USA, pp. 1-7.

Frisvold, G., Reeves, J.M., and Tronstad, R., 2006. Bt cotton adoption in the United State and China: International trade and welfare effects. AgBioForum 9: 69-78.

Glare, T.R., and O'Callaghan, M., 2000. Bacillus Thuringiensis: Biology, Ecology and Safety. Wiley, NY, USA.

Gouse, M., Pray, C., and Schimmelpfennig, D., 2004. The distribution of benefits from Bt cotton adoption in South Africa. AgBioForum 7: 187-194.

Green, W.M., deBillott, M.C., Joffe, T., vanStaden, L., Bennet-Nel, A., duToit, C.L.N., and vanderWesthuizen, L., 2003. Indigenous plants and weeds on the Maktathini Flats as refuge hosts to maintain bollworm population susceptibility to transgenic cotton (Bollgard ${ }^{\mathrm{TM}}$ ). African Entomology 11: 21-29.

Gunning, R.V., Dang, H.T., Kemp, F.C., Nicholson, I.C., and Moores, G.D., 2005. New resistance mechanism in Helicoverpa armigera threatens transgenic crops expressing Bacillus thuringiensis Cry1Ac toxin. Applied and Environmental Microbiology 71: 2558-2563.

Hargreaves, H., 1948. List of the Recorded Cotton Insects of the World. Commonwealth Institute of Entomology, London, UK.

Harwood, J.D., Wallin, W.G., and Obrycki, J.J., 2005. Uptake of Bt endotoxins by non-target herbivores and higher order arthropod predators: Molecular evidence from a transgenic corn agroecosystem. Molecular Ecology 14: 2815-2823.

Head, G., Surber, J.B., Watson, J.A., Martin, J.W., and Duan, J.J., 2002. No detection of Cry1Ac protein in soil after multiple years of transgenic Bt cotton (Bollgard) use. Environmental Entomology 31: 30-36.

Head, G., Moar, M., Eubanks, M., Freeman, B., Ruberson, J., Hagerty, A., and Turnipseed, S., 2005. A multiyear, large-scale comparison of arthropod populations on commercially managed Bt and non-Bt cotton fields. Environmental Entomology 34: 1257-1266.

Henneberry, T.J., and Naranjo, S.E., 1998. Integrated management approaches for pink bollworm in the southwestern United States. Integrated Pest Management Reviews 3: 31-52.

Herdt, R.W., 2006. Biotechnology in agriculture. Annual Review of Environment and Resources 31: 265-295.

Herring, R.J., 2007. Stealth seeds: Bioproperty, biosafety, biopolitics. Journal of Developmental Studies 43: 130-157.

Herron, G., and Wilson, L.J., 2006. Insecticide resistance in cotton aphid and two-spotted spider mite: Seasons 2004-2005 and 2005-2006. In: Proceedings of the 13th Australian Cotton Conference, Australian Cotton Growers Research Association, Narrabri, New South Wales, Australia, pp. 491-495.

Heuberger, S.M., 2006. Contamination of refuges by transgenic Bt cotton: Implications for pink bollworm resistance. Master's thesis, University of Arizona, Tucson, AZ, USA, 84 pp.

Ilyas, M., 2004. Researchers employ genetic engineering: Cotton varieties. Grain, Barcelona, Spain. http://www.grain.org/research/btcotton.cfm?id = 155 (accessed 12 March 2008). 
James, C., 2006. Global Status of Commercialized Biotech/GM Crops: 2006. ISAAA Brief No. 35, International Service for the Acquisition of Agri-Biotech Applications, Ithaca, NY, USA. James, C., 2007. Global Status of Commercialized Biotech/GM Crops: 2007. ISAAA Brief No. 37, International Service for the Acquisition of Agri-Biotech Applications, Ithaca, NY, USA. Jayaraman, K.S., 2001. Illegal Bt-cotton in India haunts regulators. Nature Biotechnology 19: 1090.

Jayaraman, K.S., 2002. India approves GM cotton. Nature Biotechnology 20: 415.

Jayaraman, K.S., 2004. India produces homegrown GM cotton. Nature Biotechnology 22: $255-256$.

Jenkins, J.N., and Wilson, F.D., 1996. Host plant resistance. In: Cotton Insects and Mites: Characterization and Management, E.G., King, J.R. Phillips and R.J. Coleman, eds., The Cotton Foundation Publisher, Memphis, TN, USA, pp. 563-600.

Jia, S., 2001. Transgenic Cotton. Science Press, Beijing, China.

Kambhampati, U., Morse, S., Bennett, R., and Ismael, Y., 2006. Farm-level performance of genetically modified cotton: A frontier analysis of cotton production in Maharashtra. Outlook on Agriculture 35: 291-297.

Khan, M., Quade, A., and Murray, D., 2006. Mirid management - effect of salt rate when mixed with reduced rates of chemical. In: Proceedings of the 13th Australian Cotton Conference, Australian Cotton Growers Research Association, Narrabri, New South Wales, Australia, pp. 537-542.

King, E.G., Coleman, R.J., Morales-Ramos, J.A., Summy, K.R., Bell, M.R., and Snodgras, G.L., 1996. Biological control. In: Cotton Insects and Mites: Characterization and Management, E.G., King, J.R. Phillips and R.J. Coleman, eds., The Cotton Foundation Publisher, Memphis, TN, pp. 511-538.

Kogan, M., 1998. Integrated pest management: Historical perspectives and contemporary developments. Annual Review of Entomology 43: 243-270.

Kovach, J., Petzoldt, C., Degni, J., and Tette, J., 1992. A method to measure the environmental impact of pesticides. New York Food and Life Sciences Bulletin, New York State Agricultural Experiment Station, Cornell University, Geneva, NY, USA. http://www.nysipm.cornell.edu/ publications/eiq/default.asp (accessed 12 March 2008).

Kranthi, M., Dhawd, C.S., Naidu, K., Mate, K., Patil, E., and Kranthi, S., 2005. Bt cotton seed as a source of Bacillus thuringiensis insecticidal toxin for bioassays to detect and monitor bollworm resistance to Bt cotton. Current Science 88: 796-800.

Lachnicht, S.L., Hendrix, P.F., Potter, R.L., Coleman, D.C., and Crossley, D.A., 2004. Winter decomposition of transgenic cotton residue in conventional-till and no-till systems. Applied Soil Ecology 27: 135-142.

Lei, T., Khan, M., and Wilson, L., 2003. Boll damage by sucking pests: An emerging threat, but what do we know about it? In: World Cotton Research Conference III: Cotton for the New Millennium, A. Swanepoel, ed., Agricultural Research Council - Institute for Industrial Crops, Cape Town, South Africa, pp. 1337-1344.

Li, G.P., Wu, K.M., Gould, F., Wang, J.K., Miao, J., Gao, X.W., and Gao, Y.Y., 2007. Increasing tolerance to Cry1 Ac cotton from cotton bollworm, Helicoverpa armigera, was confirmed in $\mathrm{Bt}$ cotton farming area of China. Ecological Entomology 32: 366-375.

Llewellyn, D., and Fitt, G., 1996. Pollen dispersal from two field trials of transgenic cotton in the Namoi Valley, Australia. Molecular Breeding 2: 157-166.

Llewellyn, D., Tyson, C., Constable, G., Duggan, B., Beale, S., and Steel, P., 2007. Containment of regulated genetically modified cotton in the field. Agriculture Ecosystems and Environment 121: 419-429.

Mahon, R., Olsen, K., Downes, S., and Addison, S., 2007. Frequency of alleles conferring resistance to the Bt toxins Cry1 Ac and Cry2Ab in Australian populations of Helicoverpa armigera (Hübner) (Lepidoptera: Noctuidae). Journal of Economic Entomology 100: 894-902.

Manjunath, T.M., 2005. Safety of Bt cotton: Facts allay fear. http://www.agbioworld.org/biotechinfo/articles/biotech-art/safety-bt-cotton.html (accessed 12 March 2008). 
Marvier, M., McCreedy, C., Regetz, J., and Kareiva, P., 2007. A meta-analysis of effects of Bt cotton and maize on non-target invertebrates. Science 316: 1475-1477.

Men, X., Ge, F., Edwards, C.A., and Yardim, E.N., 2005. The influence of pesticide applications on Helicoverpa armigera Hubner and sucking pests in transgenic Bt cotton and non-transgenic cotton in China. Crop Protection 24: 319-324.

Mensah, R., and Macpherson, I., 2006. Attracting and killing moths on Bollgard?II ${ }^{\circledR}$ cotton crops: A new strategy for managing Helicoverpa spp. on conventional cotton crops. In: Proceedings of the 13th Australian Cotton Conference, Australian Cotton Growers Research Association, Narrabri, New South Wales, Australia, pp. 555-565.

Mensah, R., Coates, R., and Hoque, Z., 2004. Petroleum spray oils - lubricating the path to IPM. Part 4. Use of synthetic insecticides and petroleum spray oil combinations for improved efficacy against Helicoverpa spp. and green mirids on cotton crops. In: Proceedings of the 12th Australian Cotton Conference, Australian Cotton Growers Research Association, Narrabri, New South Wales, Australia, pp. 699-710.

Monsanto, 2007. Putting technology to work in the field 2007. R\&D pipeline at a glance. http:// www.monsanto.com/pdf/products/productPipeline.pdf (accessed 12 March 2008).

Naranjo, S.E., 2001. Conservation and evaluation of natural enemies in IPM systems for Bemisia tabaci. Crop Protection 20: 835-852.

Naranjo, S.E., 2005. Long-term assessment of the effects of transgenic Bt cotton on the function of the natural enemy community. Environmental Entomology 34: 1211-1223.

Naranjo, S.E., and Luttrell, R.G., 2008. Cotton arthropod IPM. In: Integrated Pest Management, E. B. Radcliff and W.D. Hutchison, eds., Cambridge University Press, Cambridge, UK (in press).

Naranjo, S.E., Ellsworth, P.C., and Hagler, J.R., 2004. Conservation of natural enemies in cotton: Role of insect growth regulators in management of Bemisia tabaci. Biological Control 30: 52-72.

Naranjo, S.E., Head, G., and Dively, G.P., 2005. Field studies assessing arthropod non-target effects in Bt transgenic crops: Introduction. Environmental Entomology 34: 1178-1180.

Obrist, L.B., Dutton, A., Albajes, R., and Bigler, F., 2006a. Exposure of arthropod predators to Cry $1 \mathrm{Ab}$ toxin in Bt maize fields. Ecological Entomology 31: 143-154.

Obrist, L.B., Dutton, A., Romeis, J., and Bigler, F., 2006b. Biological activity of Cry1Ab expressed by $\mathrm{Bt}$ maize following ingestion by herbivorous arthropods and exposure of the predator Chrysoperla carnea. BioControl 51: 31-48.

Obrycki, J.J., Ruberson, J.R., and Losey, J.E., 2004. Interactions between natural enemies and transgenic insecticidal crops. In: Genetics, Evolution and Biological Control, L.E. Ehler, R. Sforza and T. Mateille, eds., CABI, Wallingford/Oxon, UK, pp. 183-206.

O’Callaghan, M., Glare, T.R., Burgess, E.P.J., and Malone, L.A., 2005. Effects of plants genetically modified for insect resistance on non-target organisms. Annual Review of Entomology 50: 271-292.

Pilcher, C.D., Rice, M.E., and Obrycki, J.J., 2005. Impact of transgenic Bacillus thuringiensis corn and crop phenology on five non-target arthropods. Environmental Entomology 34: 1302-1316.

Poehlman, J.M., 1987. Breeding cotton. In: Breeding Field Crops, 3rd edition, J.M. Poehlman, ed., Van Nostrand Reinhold Publisher, New York, USA, pp. 556-591.

Pray, C., Huang, J., Ma, D., and Qiao, F., 2001. Impact of Bt cotton in China. World Development 29: 813-825.

Price, G.K., Lin, W., Falck-Zepeda, J.B., and Fernandez-Cornejo, J., 2003. The size and distribution of market benefits from adopting agricultural biotechnology. United States Department of Agriculture, Economic Research Service, Technical Bulletin \#1906.

Pschorn-Strauss, E., 2005. Bt cotton in South Africa: The case of the Makhathini farmers. Grain. http://www.grain.org/seedling/?id = 330 (accessed 12 March 2007).

Pyke, B., 2008. The impact of high adoption of BollgardII cotton on pest management in Australia. In: Proceedings of the World Cotton Research Conference, Lubbock, TX, USA, 9-15 September 2007 (in press).

Qaim, M., and DeJanvry, A., 2005. Bt cotton and pesticide use in Argentina: Economic and environmental effects. Environmental and Developmental Economics 10: 179-200. 
Qaim, M., Subramanian, A., Naik, G., and Zilberman, D., 2006. Adoption of Bt cotton and impact variability: Insights from India. Review of Agricultural Economics 28: 48-58.

Raney, T., 2006. Economic impact of transgenic crops in developing countries. Current Opinion in Biotechnology 17: 174-178.

Romeis, J., and Shanower, T.G., 1996. Arthropod natural enemies of Helicoverpa armigera (Hübner) (Lepidoptera: Noctuidae) in India. Biocontrol Science and Technology 6: 481-508.

Romeis, J., Meissle, M., and Bigler, F., 2006. Transgenic crops expressing Bacillus thuringiensis toxins and biological control. Nature Biotechnology 24: 63-71.

Rossiter, L., and Kauter, G., 2006. Helicoverpa armigera insecticide resistance management - key considerations for 2006-2007. In: Proceedings of the 13th Australian Cotton Conference, Australian Cotton Growers Research Association, Narrabri, New South Wales, Australia, pp. 521-524.

Sanvido, O., Romeis, J., and Bigler, F., 2007. Ecological impacts of genetically modified crops: Ten years of field research and commercial cultivation. Advances in Biochemical Engineering and Biotechnology 107: 235-278.

Schuler, T.H., Denholm, I., Clark, S.J., Stewart, C.N., and Poppy, G.M., 2004. Effects of Bt plants on the development and survival of the parasitoid Cotesia plutellae (Hymenoptera: Braconidae) in susceptible and Bt-resistant larvae of the diamondback moth, Plutella xylostella (Lepidoptera: Plutellidae). Journal of Insect Physiology 50: 435-443.

Shankar, B., and Thirtle, C., 2005. Pesticide productivity and transgenic cotton technology: The South African smallholder case. Journal of Agricultural Economics 56: 97-115.

Sharma, H.C., ed., 2005. Heliothis/Helicoverpa Management: Emerging Trends and Strategies for Future Research. Oxford/IBH, New Delhi, India.

Sharma, H.C., and Ortiz, R., 2000. Transgenics, pest management and the environment. Current Science 79: 421-437.

Sharma, O.P., Bambawale, O.M., Dhandapani, A., Tanwar, R.K., Bhosle, B.B., Lavekar, R.C., and Rathod, K.S., 2005. Assessment of severity of important diseases of rainfed $B t$ transgenic cotton in Southern Maharashtra. Indian Phytopathology 58: 483-485.

Sharma, H.C., Arora, R., and Pampapathy, G., 2007. Influence of transgenic cottons with Bacillus thuringiensis crylAc gene on the natural enemies of Helicoverpa armigera. BioControl 52: 469-489.

Shelton, A.M., Zhao, J.Z., and Roush, R.T., 2002. Economic, ecological, food safety, and social consequences of the deployment of Bt transgenic plants. Annual Review of Entomology 47: 845-881.

Shen, R.F., Cai, H., and Gong, W.H., 2006. Transgenic Bt cotton has no apparent effect on enzymatic activities or functional diversity of microbial communities in rhizosphere soil. Plant and Soil 285: 149-159.

Shiva, V., and Jafri, A.J., 2003. Failure of the GMO's in India. http://www.mindfully.org/GE/2003/ India-GMO-Failure-Shiva31may03.htm (accessed 12 March 2008).

Simmons, A.L., Dennehy, T.J., Tabashnik, B.E., Antilla, L., Bartlett, A., Gouge, D., and Staten, R., 1998. Evaluation of Bt cotton deployment strategies and efficacy against pink bollworm in Arizona. In: Proceedings of the Beltwide Cotton Conferences, National Cotton Council, Memphis, TN, USA, pp. 1025-1030.

Sisterson, M.S., and Tabashnik, B.E., 2005. Simulated effects of transgenic Bt crops on specialist parasitoids of target pests. Environmental Entomology 34: 733-742.

Sisterson, M.S., Biggs, R.W., Olson, C., Carrière, Y., Dennehy, T.J., and Tabashnik, B.E., 2004. Arthropod abundance and diversity in Bt and non-Bt cotton fields. Environmental Entomology 33: 921-929.

Sithanantham, S., Singh, S.P., and Romeis, J., 2005. Biological control of Helicoverpa: Research status, constraints and opportunities. In: Heliothis/Helicoverpa Management: Emerging Trends and Strategies for Future Research, H.C. Sharma, ed., Oxford/IBH, New Delhi, India, pp. 329-369.

Smale, M., Zambrano, P., and Cartel, M., 2006. Bales and balances: A review of the methods used to assess the economic impact of Bt cotton on farmers in developing economies. AgBioForum 9: $195-212$. 
Snodgrass, G.L., Scott, W.P., Abel, C.A., Robbins, J.T., Gore, J., and Hardee, D.D., 2006. Suppression of tarnished plant bugs (Heteroptera: Miridae) in cotton by control of early season wild host plants with herbicides. Environmental Entomology 35: 1417-1422.

Steinkraus, D.C., Hollingsworth, R.G., and Boys, G.O., 1996. Aerial spores of Neozygites fresenii (Entomophthorales: Neozygitaceae): Density, periodicity, and potential role in cotton aphid (Homoptera: Aphididae) epizootics. Environmental Entomology 25: 48-57.

Sunilkumar, G., Campbell, L.M., Puckhaber, L., Stipanovic, R.D., and Rathore, K.S., 2006. Engineering cottonseed for use in human nutrition by tissue-specific reduction of toxic gossypol. Proceedings of the National Academy of Sciences of the USA 103: 18054-18059.

Tabashnik, B.E., Patin, A.L., Dennehy, T.J., Liu, Y.B., Miller, E., and Staten, R.T., 1999. Dispersal of pink bollworm (Lepidoptera: Gelechiidae) males in transgenic cotton that produces a Bacillus thuringiensis toxin. Journal of Economic Entomology 92: 772-780.

Tabashnik, B.E., Carrière, Y., Dennehy, T.J., Morin, S., Sisterson, M.S., Roush, R.T., Shelton, A.M., and Zhao, J.Z., 2003. Insect resistance to transgenic Bt crops: Lessons from the laboratory and field. Journal of Economic Entomology 96: 1031-1038.

Tabashnik, B.E., Gassmann, A.J., Crowder, D.W., and Carriere, Y., 2008. Insect resistance to Bt crops: evidence versus theory. Nature Biotechnology 26: 199-202.

Torres, J.B., and Ruberson, J.R., 2006. Interactions of Bt-cotton and the omnivorous big-eyed bug Geocoris punctipes (Say), a key predator in cotton fields. Biological Control 39: 47-57.

Torres, J.B., and Ruberson, J.R., 2008. Interactions of Bacillus thuringiensis Cry1Ac toxin in genetically engineered cotton with predatory heteropterans. Transgenic Research 17: 345-354.

Torres, J.B., Ruberson, J.R., and Adang, M.J., 2006. Expression of Bacillus thuringiensis Cry1Ac protein in cotton plants, acquisition by pests and predators: A tritrophic analysis. Agricultural and Forest Entomology 8: 191-202.

Traxler, G., and Godoy-Avila, S., 2004. Transgenic cotton in Mexico. AgBioForum 7: 57-62.

Trichilo, P.J., and Wilson, L.T., 1993. An ecosystem analysis of spider mite outbreaks: Physiological stimulation or natural enemy suppression. Experimental and Applied Acarology 17: 291-314.

USDA (United States Department of Agriculture), 2006. Cotton Varieties Planted: 2006 Crop. U.S. Department of Agriculture, Agricultural Marketing Service - Cotton Program, Memphis, TN, USA.

USDA (United States Department of Agriculture), 2007. Cotton Varieties Planted: 2007 Crop. U.S. Department of Agriculture, Agricultural Marketing Service - Cotton Program, Memphis, TN, USA.

USEPA (United States Environmental Protection Agency), 2007. Insecticide resistance management fact sheet for Bacillus thuringiensis (Bt) cotton products. http://www.epa.gov/pesticides/ biopesticides/pips/bt_cotton_refuge_2006.htm (accessed 12 March 2008).

Whitcomb, W.H., and Bell, K., 1964. Predaceous insects, spiders and mites of Arkansas cotton fields. Arkansas Agricultural Experiment Station Bulletin 690: 1-84.

Whitehouse, M., Wilson, L., and Constable, G., 2007. Target and non-target effects on the invertebrate community of Vip cotton, a new insecticidal transgenic. Australian Journal of Agricultural Research 58: 273-285.

Williams, M.R., 2006. Cotton insect losses 2005. In: Proceedings of the Beltwide Cotton Conferences, National Cotton Council, Memphis, TN, USA, pp. 1151-1204.

Wilson, L.J., 1994. Resistance of okra-leaf cotton genotypes to two-spotted spider mites (Acari: Tetranychidae). Journal of Economic Entomology 87: 1726-1735.

Wilson, L.J., Bauer, L.R., and Lally, D.A., 1998. Effect of early season insecticide use on predators and outbreaks of spider mites (Acari: Tetranychidae) in cotton. Bulletin of Entomological Research 88: 477-488.

Wilson, L.J., Mensah, R.K., and Fitt, G.P., 2004. Implementing integrated pest management in Australian cotton. In: Novel Approaches to Insect Pest Management in Field and Protected Crops, A.R. Horowitz and I. Ishaaya, eds., Springer, Berlin, pp. 97-118. 
Wilson, L., Hickman, M., and Deutscher, S., 2006. Research update on IPM and secondary pests. In: Proceedings of the 13th Australian Cotton Research Conference, Broadbeach, Queensland, Australia, pp. 249-258.

Wolfenbarger, L.L., Naranjo, S.E., Lundgren, J.G., Bitzer, R.J., and Watrud, L.S. 2008. Bt Crop effects on functional guilds of non-target arthropods: A meta-analysis. PLoS ONE 3(5): e2118. doi:10.137/journal.pone.0002118.

$\mathrm{Wu}, \mathrm{K} ., 2007 \mathrm{a}$. Monitoring and management strategy of Helicoverpa armigera resistance to $\mathrm{Bt}$ cotton in China. Journal of Invertebrate Pathology 95: 220-223.

Wu, K., 2007b. Environmental impacts of Bt cotton commercialization and strategy for risk management. Journal of Agricultural Biotechnology 15: 1-4.

Wu, K., Guo, Y., and Gao, S., 2002a. Evaluation of the natural refuge function for Helicoverpa armigera (Hübner) within Bt transgenic cotton growing areas in north China. Journal of Economic Entomology 95: 832-837.

Wu, K., Li, W., Feng, H., and Guo, Y., 2002b. Seasonal abundance of the mirids, Lygus lucorum and Adelphocoris spp. (Hemiptera: Miridae) on Bt cotton in northern China. Crop Protection 21: 997-1002.

Wu, K., Feng, H., and Guo, Y., 2004. Evaluation of maize as a refuge for management of resistance to Bt cotton by Helicoverpa armigera (Hubner) in the Yellow River cotton farming region of China. Crop Protection 23: 523-530.

Wu, K., Guo, Y., and Head, G., 2006. Resistance monitoring of Helicoverpa armigera (Lepidoptera: Noctuidae) to Bt insecticidal protein during 2001-2004 in China. Journal of Economic Entomology 99: 893-896.

Wu, K.M., and Guo, Y.Y., 2003. Influences of Bacillus thuringiensis Berliner cotton planting on population dynamics of the cotton aphid, Aphis gossypii Glover, in northern China. Environmental Entomology 32: 312-318.

Wu, K.M., and Guo, Y.Y., 2005. The evolution of cotton pest management practices in China. Annual Review of Entomology 50: 31-52.

Zhao, J.Z., 1984. Species distribution and population fluctuation of predacious spiders in cotton fields in China. Natural Enemies of Insects 6: 1-12. 